\title{
DELIVERED PRICING AS CONSPIRACY AND AS DISCRIMINATION: THE LEGAL STATUS
}

\author{
BUEFORd G. HerberT*
}

I

INTRODUCTION

The delivered price systems here considered are not novel or recent things, but are practices which businessmen have used for approximately half a century. It is not strange that any action which threatens to jeopardize methods of pricing which have become to most businessmen settled and accustomed business practices should meet with bitter opposition. Businessmen plead only for certainty in "the rules of the game" and contend that their honest desire to follow the law is thwarted by the confusion into which the law has been plunged by recent court decisions and administrative action. Spokesmen for the Federal Trade Commission, the government agency whose activities have done most to affect the legality of these pricing practices, contend that the confusion is largely of the businessmen's own making, and that the Commission has attempted only to maintain the competitive system of free enterprise through vigorous enforcement of the antitrust statutes.

A lawyer is certain to be rather cautious in attempting to analyze the legal aspects of such a controversial subject which is so intertwined with economic problems and has such an important bearing on business interests. He also naturally is loath to make emphatic statements as to what the law is or will be when the decided cases are relatively few, and reliance must be placed upon what can be properly characterized only as dictum. In such instances he realizes that his opinion is little more than a well-informed guess-sometimes, perhaps, not too well informed. His opinion is apt to be hedged with many "ifs," "buts," and provisos. This accounts, at least in part, for the present conflict and seeming confusion in the expressions of opinion as to the legal status of delivered price systems.

The delivered price systems here considered are of two general types: basing point systems and zone systems. Included in the basing point category are the single basing point, multiple basing point, and freight equalization systems. The freight equalization system is sometimes referred to as the plenary basing point system, as each point of production is a basing point. In basing point systems the delivered price quoted is arrived at by adding to a base price established at some certain plant or geographical point, the freight charge from that point to the buyer's

- LL.B. I948, University of Louisville; LL.M. I949, Duke University. Member of the Kentucky bar. Assistant Professor of Law and Associate Editor, Law and Contemporary Problems, Duke University, since 1949 . 
destination. The freight charge or factor which is added to the base price may or may not be the actual cost of transporting the article.

The zone systems are of two types: the multiple zone and the single zone, often called the uniform delivered price or universal delivered price system. These systems involve quoting uniform delivered prices within a certain geographic area, which may be as small as a single state, or may include the whole country.

The federal statutes involved in a consideration of the legal aspects of delivered pricing practices are those known as the antitrust statutes. They are the Sherman Act of $1890,{ }^{1}$ the Federal Trade Commission Act of ${ }_{1914},{ }^{2}$ the Clayton Act of $\mathrm{r}_{914}{ }^{3}$ and the Robinson-Patman Act of $1936^{4}$ which amended Section 2 of the Clayton Act. The legal status of these pricing systems is here considered separately under the several statutes. Although this article attempts to speak only as to the legal aspects of these delivered price systems, it should be pointed out that the solutions to the legal problems involved depend to a great extent upon the results of economic analysis, and an understanding of at least some of the economic aspects of these systems is essential to an understanding of the legal problems.

II

\section{The Sherman Act}

Since the Sherman Act is aimed against monopolies and against contracts, combinations, and conspiracies in restraint of trade, a delivered price system raises problems under this Act only when it is connected in some way with such activities. The principal question in deciding the legality of the delivered price systems under this Act has been whether the system was based on collusive or concerted action in restraint of competition. Therefore, the cases under the Sherman Act involving the use of delivered price systems do not present the issue of the legality per se of these systems. The early cases were decided at a time when the government was first becoming aware of the problem of delivered pricing, and the seeming inconsistency of some of them with later decisions may result from a failure on the part of the prosecution to develop and present its case in an adequate manner. It may of course reflect changes in the membership of the United States Supreme Court since some of these earlier cases were decided, and corresponding changes of judicial thinking on the subject.

The earliest cases which involved the use of a delivered price system to be decided under the Sherman Act belonged to a series in which the "open price" policies of the trade associations were attacked. ${ }^{5}$

\footnotetext{
126 STAT. 209 (1890), I5 U. S. C. \$I-7 (1946).

${ }^{2} 38$ Stat. 7I7 (I9I4), as amended. by 52 STAT. III (1938), 15 U. S. C. $\$ 4$ I et seq. (I946).

${ }^{3} 38$ STAT. 730 (1914), I5 U. S. C. \$13 (1946).

49 STAт. 15266 (1936), 15 U. S. C. \$13 (1946).

- American Column and Lumber Co. v. United States, 257 U. S. 377 (1921); Maple Flooring Ass'n v. United States, 268 U. S. 563 (1925); Cement Mfgrs. Protective Ass'n v. United States, 268 U. S. 588
} (1925). 
The members of each of the trade associations involved in these cases were using a basing point system to quote delivered prices for their products. In these cases the Supreme Court failed to see any grounds for inferring that the identical prices under the basing point system were the result of understanding, or that the use of the system represented a concerted effort to restrain competition. This may have been because of faulty presentation of the charges by the government, in that it failed in these cases to allege collusive action among the users of the system, and only weakly contended that an inference of collusion or agreement should be drawn from the mechanics of the system and the results of its use.

In the Maple Flooring case the Court did indicate that if the basing point system was used to implement an agreement to fix or maintain prices, or if it had produced concerted action to fix or maintain prices, the entire scheme would have been held to be an unlawful restraint of trade.

In the Cement case the fact that the Court could view the system as a product of natural growth in a competitive industry seems particularly strange. This would seem to indicate that the government could have made a much better presentation of the economic aspects of the system.

The most important case involving the legality of the basing point system under the Sherman Act to reach the Supreme Court was Sugar Institute, Inc. v. United States. ${ }^{\circ}$

The lower court held that the concerted maintenance of a basing point delivered price system, which included the concerted use of freight factors which were not the actual cost of delivery, and a refusal to sell f.o.b. refinery, was an unreasonable and illegal restraint of trade. The defendants waived their assignment of error on this point and also on that part of the decree which enjoined concerted action in "determining transportation charges or freight applications to be collected from customers, or limiting freight absorptions; selling only on delivered prices or on any system of delivered prices, including zone prices or refusing to sell f.o.b. refinery." T

Although there was present a broad price fixing scheme, the basing point system was not examined merely as one of the devices used to implement the scheme, but was considered apart with respect to the question of whether its concerted use constituted an unreasonable restraint of trade in violation of Section I of the Sherman Act. The direct holding of the lower court was that the concerted use of the basing point system was an unreasonable restraint of trade and unlawful. ${ }^{8}$ The Supreme

${ }^{\circ} 297$ U. S. 553 (1936).

T United States v. Sugar Institute, I5 F. Supp. 817, 908 (S. D. N. Y. I934).

${ }^{8}$ There has been considerable dispute as to whether the court's decision brought the concerted use of a basing point system within the doctrine of per se violations of the Sherman Act, or whether the effect of its use upon competition bad to be examined to determine if the restraint on competition was so unreasonable as not to fall within the ambit of the "rule of reason," adopted in Standard Oil Co. of New Jersey v. United States, 221 U. S. I (rgII).

One line of reasoning is that: "Under this reasoning any agreement to use a basing point system would be unlawful as an agreement to fix a part of the delivered price since the predetermined freight 
Court did not pass upon this holding but it did state that, "The unreasonable restraint which defendants imposed lay not in advance announcements, but in the steps taken to secure adherence, without deviation, to prices and terms thus announced." Since the basing point sytem was the means used to secure adherence to the prices announced, this would seem to be an approval of the lower court's conclusion as to the illegality of its concerted use.

There have been two cases involving zone delivered price systems decided by the Supreme Court under the Sherman Act, but in both an agreement or combination in restraint of trade was found on other grounds and the delivered price system was mentioned only incidentally. ${ }^{10}$

The fact that in all these cases arising under the Sherman Act the delivered price system was only one among many activities attacked as restraining trade makes it difficult to spell out any clear conclusions as to the legal status of delivered price systems under the Act. However, it does seem clear from a consideration of these cases that any collusive or concerted use of the basing point system, or any use of

rates employed are usually higher than necessary, owing to the collection of phantom freight and the quoting of all rail tariffs, and consequently unreasonable. Thus concerted action in maintaining a basing point system, is a type of price fixing." Comment, Basing Point Pricing and Anti-Trust Policy, 55 YALE L. J. 558, 574 (I946).

This is, of course, an attempt to bring the concerted use of the basing point system under the per se doctrine as expressed in United States v. Trenton Potteries Co., 273 U. S. 392 (1927), on the theory that there is collusion in fixing the actual delivered price to be charged. In the same article the writer recognizes the most obvious vice of collusive use of the system by remarking that if agreements for uniform price maintenance are illegal, then agreements to adopt a system which necessarily leads to that result should also be declared illegal. The Supreme Court early indicated that agreements for uniform price maintenance are illegal by its statement in the Cement case that "agreements or understandings among competitors for the maintenance of uniform prices are of course unlawful." 268 U. S. 588, 604 (rg25).

In United States v. American Linseed Oil Co., 262 U. S. 371 (r923), the Court held that a trade association's activities, the fundamental activity being an agreement to adhere to announced prices, nceessarily resulted in an illegal restraint of trade. Likewise in this case the Court said that the unreasonable restraints were the steps taken to secure adherence to the prices publicly announced.

Since the decision in United States v. Socony-Vacuum Oil Co., 310 U. S. 150 (I940), there seems to be no room to dispute that agreements to maintain identical prices or to adhere to announced prices are illegal. Since the purpose and necessary result of the concerted used of a basing point system is the maintenance of identical delivered prices at all points, and adherence to the announced base price is an essential part of the concerted action, it necessarily follows that an agreement to use the basing point system is a per se violation of the Sherman Act.

The Federal Trade Commission had this to say about collusive use of the basing point system: "Where the geographic pricing formula is significantly involved, its importance springs from the fact that it is used as a price fixing device and that analysis of its operation provides evidence that there has been a collusive agreement. It is always possible for businessmen, instead of agreeing to prices directly, to agree instead that they will all use a formula which has the effect of making their prices identical." FTC, Notice to the Staff: In Re: Commsston Policy Toward Geooraphic Pricing Practices (Oct. I2, x948).

All do not agree that concerted use of the system is a per se violation, however: "Even assuming the existence of a combination to use the basing point system, it must still be decided whether the combination constitutes an unlawful restraint upon trade." Note, Multiple Basing Point Pricing in the Cement Industry, 42 ILr. L. Rev. 364, 369 (1947). See also Note, Anti-Trust Law-Cement IndusiryLegality of Multiple Basing Point Pricing System, 95 U. oF PA. L. REv. 408 (1947).

- Sugar Institute, Inc. v. United States, 297 U. S. 553, 601 (1936).

${ }^{10}$ Standard Sanitary Mfg. Co. v. United States, 226 U. S. 20 (IgI2); United States v. American Linseed Oil Co., 262 U. S. 37 (1923). 
the system to facilitate or effectuate any agreement, conspiracy, understanding, or concerted action with respect to prices is such a restriction and restraint on competition as to be unlawful under Section I of the Sherman Act. There seems to be no peculiar characteristic of the basing point system which should lead us to think that the same rule would not be applicable to the other delivered price systems, although there is a paucity of authority in the form of decided cases to support such a conclusion. ${ }^{11}$

III

\section{The Frderal Trade Commission Act}

It has been the action of the Federal Trade Commission which has done most to clarify or, as some would have it, to confuse the legal status of delivered price systems. The Commission has proceeded against such systems both under the Federal Trade Commission Act and the amended Clayton Act. Here we will consider only its action under the former statute.

The Commission is given authority by the Federal Trade Commission Act to prevent the use of unfair methods of competition in interstate commerce. The Commission has proceeded against agreements or combinations in restraint of trade as constituting unfair methods of competition within the meaning of the Act, and it has been definitely decided by the Supreme Court that the term "unfair methods of competition" in Section 5 of the Federal Trade Commission Act includes violations of the Sherman Act. ${ }^{12}$ Most of the Commission's proceedings against delivered price systems have been based upon charges of activity which would also be illegal under the Sherman Act. These cases are based upon charges that the delivered price system is being collusively used as a price fixing device. Since a concerted or collusive use of a delivered price system, or use of the system to effectuate any agreement, conspiracy, understanding, or concerted action with respect to prices is unlawful under the Sherman Act, it is the manner in which the Commission has proved such use of the system that is of particular significance here.

The Commission's method of proving prohibited use of the delivered price systems has been the main object of criticism directed against it in its proceedings under the Federal Trade Commission Act. The Commission has been accused of assuming that wherever a delivered price system has been used by several sellers there has been a conspiracy or concerted action to adopt or maintain the system. ${ }^{13}$

\footnotetext{
11 In this connection it should be noted that the decree in the Sugar Institute case enjoined concerted. action in "selling only on delivered prices or on any system of delivered prices including zone prices or refusing to sell f.o.b. refinery." I5 F. Supp. 817, 908 (S. D. N. Y. 1934).

${ }^{12}$ Federal Trade Comm'n v. Pacific States Paper Trade Ass'n, 273 U. S. 52 (1927), was the first case in which the Supreme Court upheld the Commission's authority to proceed against price fixing as an unfair method of competition. Many cases have indicated that "unfair methods of competition" embraced all Sherman Act violations, but in Federal Trade Comm'n v. Cement Institute, 333 U. S. 683, 69o (r948), the Court directly held that this was the case.

1s "It is recognized that aggressive competition may result in a virtual identity of prices. It is also suggested that an unlawful price conspiracy will achieve price identity. Yet the committee will discover that a considerable part of the present uncertainty flows from the insistence of Government, and par-
} 
It must be remembered, however, that an order under the Act does not require a finding of a conspiracy or combination to restrain trade. Practices which have a dangerous tendency unduly to hinder competition or create monopoly have been held to be "unfair methods of competition," irrespective of the presence of conspiracy or combination. ${ }^{14}$ This principle has been applied to the delivered price field in only a very few instances, but as we shall see its relevancy there has been favorably passed upon by the Supreme Court. It is through this principle that we are most likely to get a determination of the issue of the legality per se of the various delivered price systems under the Federal Trade Commission Act.

The Federal Trade Commission's fight against delivered price systems started with its proceeding in 1924 against the United States Steel Corporation and its subsidiaries. The respondents were using a single basing system of pricing which utilized Pittsburgh as a basing point. They sold their rolled steel at the Pittsburgh base price plus freight from Pittsburgh to destination, regardless of the location of the actual shipping point. Steel manufacturers near Birmingham, Alabama sold with Birmingham as a base point. The base price at Birmingham was made up of the Pittsburgh base plus a purely arbitrary differential of $\$ 5.00$ per ton. The Commission charged that respondents by use of this pricing system discriminated in price among their customers in violation of Section 2 of the Clayton Act, and that this use constituted an unfair method of competition under Section 5 of the Federal Trade Commission Act.

The Commission's findings were that the use of the Pittsburgh plus system resulted in price discriminations which substantially lessened competition among consumers of steel, between respondents and other consumers of steel who were forced to pay the discriminatory prices, and among all producers of steel in the United States, as all producers followed the Pittsburgh plus system of the respondents. It found further that such a use of this system was an unfair method of competition. The respondents were ordered to cease and desist from selling their products on the Pittsburgh plus basis and from selling upon any other basing point than that where the products were manufactured or from which they were shipped. On 'September 17, 1924, the respondents filed a report with the Commission stating their intention of complying with the order "in so far as it is practicable to do so."

The respondents, however, did not comply with this order, but adopted a multiple basing point system of pricing instead. ${ }^{15}$ Then in $193^{8}$ the Wheeler-Lea

ticularly administrative officials, in assuming that where substantial price identity is found there must have been a conspiracy in fact." John M. Hancock, in Hearings before Subcommittee of the Committee on Interstate and Foreign Commerce on S. Res. 24I, 8oth Cong., $2 \mathrm{~d}$ Sess. 9 (I948).

"What should be painstakingly considered by the courts is the Commission's position, as revealed in its proceeding against the Cement industry ... that the nature of the basing point system is such that it is never used except for the purpose of collaborating with other sellers. . ." Hilder, The Attack Upon Delivered Price Systems, I4 GEo. WAsh. L. REv. 397, 420 (1946).

It Federal Trade Comm'n v. Gratz, 253 U. S. 42I, 427 (I9r9); Federal Trade Comm'n v. BeechNut Packing Co., 257 U. S. 44I (I92I); United States Steel Corp., 8 F. T. C. I (1924).

1. A. R. Burns, The Decline of Competition 306 (1938). 
amendment ${ }^{16}$ to the Federal Trade Commission Act made the decree of the Commission final if the respondent fails to petition a circuit court of appeals to review it. This caused the steel companies to file a petition for review in the Circuit Court of Appeals for the Third Circuit. The case remained pending until after decision of the Cement case in 1948 . The issues in the case were narrowed by the filing of ' a brief by the steel companies which was claimed to be essentially a request that the petitioners be allowed to absorb freight to meet competition. On July ro, r948, the Commission filed its brief on this question. An important statement in that brief was: ${ }^{17}$

But the oppressive nature of the practice is not confined to so-called phantom freight. If every point of shipment were to be made a basing point and all phantom freight eliminated, the system would still be oppressive to the various purchasers in that those at or near the factory door would have to pay more to that factory in order that its distant purchasers might pay less. Such is the effect of systematic freight absorption. Such is the practice that must be appraised in the light of the Supreme Court's declaration in the Staley case that a nondiscriminatory pricing system was one giving to purchasers, who have the natural advantage of proximity to its plant, "the price advantages which they are entitled to expect over purchasers at a distance." Federal Trade Commission v. Staley Mfg. Co., 324 U. S. 746, 757 .

This statement was made to support a contention that a method of competition is unfair if it involves oppression. The argument is that the discrimination inherent in the use of a basing point system is oppressive toward the nearby customers who pay the high net prices, as they in effect subsidize the cost of transportation to the more distantly located buyers. This is not a new contention, however, as such discrimination against buyers by the petitioners was found to be an unfair method of competition in the original proceeding.

It is true of course that the Commission made findings in the original proceeding that there was collusion between respondents and other steel producers to use the pricing system, and even though there was no allegation of collusion in the charge there was a charge which in effect alleged that the respondents' use of the system with knowledge that other producers would use it constituted an unfair method of competition because of its effect on competition among all steel pro ducers. ${ }^{18}$ This charge was aimed at the same type of injury to competition that would result from a price fixing conspiracy, and as we shall see is practically the

\footnotetext{
10 52 STAT. III (I938), I5 U. S. C. $\$ 45$ (1946).

${ }^{27}$ Brief for Appellees, United States Steel Corp. v. Federal Trade Comm'n, Docket No. 6796 (C. C. A. 3d 1938).

${ }^{28}$ The actual allegation was that the effect of respondents' use of the system was "to substantially lessen competition among all the producers of the said steel in the United States . . as all producers of steel in the United States adhere to the Pittsburgh Plus system and without the maintenance by respondents of the said Pittsburgh Plus, and the said Birmingham price, the other producers of said rolled steel in the United States would be unable to maintain said prices." United States Steel Corp., 8 F. T. C. I, 9 (1924).
}

The Commission found that the purpose of the system was to allow all producers to match each athers' prices. 
same as the second count in the Conduit case. ${ }^{19}$ The Commission in its recent brief in this case again asserts that this common or parallel use of the basing point system is an unfair method of competition because its effect is indistinguishable from a conspiracy to fix prices. ${ }^{20}$

This charge against the common use of the system is obviously the basis for the contention that the Commission has never proceeded against the basing point system under the Federal Trade Commission Act except where it was used in concert, and that there is no reason to suppose that it will, to be drawn from this or other deliv. ered price cases. ${ }^{21}$ The fact that the Commission did find in this case that respondents' discrimination in price was an unfair method of competition, when coupled with the argument set out in the Commission's brief that the discrimination against the nearby buyers, which is inherent in systematic freight absorption, is an unfair method of competition, does not leave one too assured that the Commission will not proceed against an individual seller's use of the basing point system under Section 5 of the Federal Trade Commission Act regardless of the incidence of the system in the industry. Since the order of the Commission in this case was never reviewed by a court, but a consent decree entered, ${ }^{22}$ the precedent value of the case is weak, although it is valuable to show the Commission's attitude toward delivered price systems and its method of attacking them.

The Commission's argument that the individual use of a basing point system is an unfair method of competition because it is oppressive seems to be based upon the old case of Federal Trade Commission v. Gratz. ${ }^{23}$ This case involved a proceeding by the Commission against a seller of cotton ties who refused to sell the ties unless the purchaser also took a certain amount of jute bagging. The Supreme

${ }^{10}$ Triangle Conduit and Cable Co. v. Federal Trade Comm'n, 168 F. 2d 175 (C. C. A. 7th 1948), aff'd per curiam sub nom. Clayton Mark \& Co. v. Federal Trade Comm'n, 336 U. S. 956 (1949).

so "The basing point system here used creates a dangerous tendency unduly to hinder competition and create monopoly by providing a device that automatically results in identical delivered prices and makes it impossible for buyers to find any price advantage in choosing among rival sellers. In other words, to the extent the basing point system here is followed, it produces the very same effect upon prices and price competition that would be produced by a combination and conspiracy to fix prices. Thus the system has more than a dangerous tendency to unduly hinder price competition. It precludes price competition per se." Brief for Appellees, United States Steel Corp. v. Federal Trade Comm'n, Docket No. 6796 (C. C. A. 3 d 1938 ).

21 "The Commission emphasizes the basing point system if it is so complicated, so rigid, and so contrary to competitive common sense in its results, that its continued existence gives persuasive cvidence of the existence of the collusion, and if it is so central that its abandonment would be likely to destroy the collusion. . . . There is no instance in which the Commission has charged that a single company using a basing point system without regard to what its competitor is doing is in violation of the Federal Trade Commission Act." Corwin D. Edwards, Director, Bureau of Industrial Economics, F. T. C., in a speech delivered at a technical seminar sponsored by the Department of Commerce for state planning and developing agencies, Washington, D. C., August 4, I948.

"The Commission has never brought a proceeding charging that freight absorption by a single seller, not accompanied by reciprocal absorption by others violates the Federal Trade Commission Act. Nor is there any reason for believing that the Commission will change its policy and make freight absorptions of this kind the target of proceedings under the Trade Commission Act." Herbert A. Bergson, Ass't Attorney General, Antitrust Division, Department of Justice, Hearings, stipra note 13, at 99.

${ }^{22}$ United States Steel Corp., Docket No. 760 (C. C. A. 3d r948).

${ }^{23} 253$ U. S. 421 (1919). 
Court affirmed the circuit court's ruling which annulled the Commission's order, solely on the ground that the complaint did not show unfair competition. The only reference to oppression by the Court was its statement as to the meaning of the words "unfair method of competition."24 This was only a very general reference as to the possible application of the concept of unfair methods of competition and is but scant support for the Commission's argument. Whether the "oppression" which the Commission found to be inherent in the use of a basing point system by a single seller would be such as to constitute an unfair method of competition is completely unsettled, and no good authority to support the contention can be cited.

If denial to the buyer of this "natural advantage of proximity to the plant" should be considered an unfair method of competition because oppressive, then every delivered price system which we are considering would be unlawful under the Federal Trade Commission Act, as this "oppression" is inherent in these systems. As will be seen when the problems arising under the Clayton Act are considered, it has never been held that denial of this "advantage" has the defined statutory effect upon competition in the second line, and the Commission has intimated that only collusive or common denial of this right is considered illegal. If the effect of this practice is not such as to constitute a violation of the Clayton Act it is doubtful if it would be held a violation of the Federal Trade Commission Act, although one member of the Commission, Allen C. Phelps, asserted that if the Conduit case was upheld in the Supreme Court, "We have now arrived at the point where a violation of the Robinson-Patman Act is also an unfair method of competition, and following the reasoning of the Supreme Court in the Cement case, unfair methods of competition may include price discriminations which fall short of violations of the Robinson-Patman Act."25

This assertion is based upon the fact that it was held in the Conduit case that conspiracy was not necessary to a finding of violation of the Federal Trade Commission Act, if the conduct had the same effect upon competition as a conspiracy. This holding does not support the assertion, however, as it contemplates the same effect upon competition, whereas Mr. Phelps' statement would include situations in which the defined statutory effect on competition was not present.

In view of the great reliance which the Supreme Court has recently placed upon the "expertness" of the Federal Trade Commission it is not inconceivable that this view if pressed will be sustained. However, after its brief was filed in the United States Steel case, the Federal Trade Commission indicated that it had abandoned this argument. ${ }^{26}$ The Commission was not so quick to abandon its argument that

26 "The words "unfair method of competition" are not defined by the statute, and their exact meaning is in dispute. It is for the courts, not the commission, ultimately to determine, as matter of law what they include. They are clearly inapplicable to practices never heretofore regarded as opposed to good morals because characterized by deception, bad faith, fraud, or oppression, or as against public policy because of their dangerous tendency unduly to hinder competition or create monopoly." Id. at 427 .

${ }^{25}$ Hearings, supra note 13 , at 133 .

20 "The problem created by freight absorption under the Federal Trade Commission Act arises, howcver, only where the result of the practice is the elimination of price competition. Freight absorption 
conscious parallel use of a basing point system with reciprocal freight absorptions, is an unfair method of competition, however, and as we shall see in our discussion of later cases this contention seems to rest upon a much sounder foundation than its arguments as to the oppression involved in the single seller's use of the system.

The Federal Trade Commission's other proceedings under Section 5 of the Federal Trade Commission Act have been confined largely to conspiracy cases in which there has been found an agreement to use the system or where the system has been found to be used as the means of effectuating an agreement or understanding on prices. Under Section 5 the Commission has entered orders against basing point conspiracies in several proceedings involving various industries. ${ }^{27}$

The first of such cases to be reviewed by the courts was United States Maltsters Association v. Federal Trade Commission. ${ }^{28}$ The complaint, directed against eighteen malt manufacturers and their trade association, charged that they had entered into an "agreement, combination, understanding and conspiracy among themselves to fix and maintain, and by which they have fixed and maintained uniform delivered prices. ....22

The Commission found that the Trade Association received reports from the members as to malt sales showing date, destination of shipment, grade and quantity of malt sold, and price received f.o.b. Chicago basis. This information was compiled by the association and distributed to the members. The Commission found further that, pursuant to agreement, whenever a member changed his price to a customer he notified the association of the new price immediately; such information was then relayed by the association to the other members.

The Commission also found an agreement to use a compilation of freight rates based upon Chicago as a base in order to compute delivered prices, to use uniform grading standards, to quote delivered prices only, to use standard seller's contracts only, and to adopt uniform discounts. It concluded that by means of these agreements and conspiracies respondents had "agreed to fix and maintain and did fix and maintain, the delivered price of malt,"30 and that this uniformity of delivered prices was achieved by use of the single basing point system.

The sole issue in the zase on review was whether the findings of the Federal Trade Commission were supported by competent evidence. The court of course refused to weigh the evidence and said, "Our function is limited solely to an in-

by a single seller, not accompanied by the reciprocal absorptions by others, raises no problem under the Federal Trade Commission Act." FTC, Statement of Policy, stipra note 8.

${ }^{27}$ Pine Hill Lime and Stone Company, 33 F. T. C. 427 (I94I); The Hardwood Institute, 34 F. T. C. 66I (1942); The Cement Institute, 37 F. T. C. 87 (r943); United States Maltsters Ass'n, 35 F. T. C. 797 (r942), modified, 37 F. T. C. 4 I9 (1943); The Milk and Ice Cream Can Institute, 37 F. T. C. 4r9 (I943); Rigid Steel Conduit Ass'n, 38 F. T. C. 534 (r944); Ferro Enamel Corporation, 42 F. T. C. 36 (1946); American Refractories Institute, No. 4900, April 13, 1948; Crown Manufacturers Ass'n of America, No. 5814, August 4, 1948.

${ }_{28} 35$ F. T. C. 797 (I942), I52 F. 2 d I6I (C. C. A. 7 th I945).

35 F. T. C. 797,800 (I942).

sold. at 809 . 
quiry as to whether the record furnishes substantial support for such findings."31 In holding that the Commission's findings were supported by substantial, competent evidence the court made certain statements which would lead one to believe that the Commission relied heavily upon the mere existence of the basing point system and the resulting identical delivered prices to support its charge of a conspiracy to fix and maintain prices. ${ }^{32}$ The truth is, however, that the court went much further than the Commission in attaching significance to the mere existence of the delivered price system. The Commission showed enough evidence of concerted activity to facilitate the basing point system to support a finding of agreement to adopt and maintain the system. It necessarily follows, therefore, that its findings of conspiracy to fix and to mantain prices were amply supported. ${ }^{33}$ The court's opinion might be important as showing that it would accept a finding of conspiracy based solely upon proof of the use of the basing point system.

Another important basing point case to reach the courts was the Milk and Ice Cream Can case. ${ }^{34}$ This is the first case involving a freight equalization plan to be reviewed. Respondents were the manufacturers of milk and ice cream cans and their trade association, the Milk and Ice Cream Can Institute. A reporting system was employed by which the members' activities, including prices received from sales, were daily made known to the Institute. The Institute members used a freight equalization plan implemented by the use of a freight rate book which made it possible to compute and quote freight rates on an equalized basis. This rate book was furnished to the members by the Institute, and the Commission found that there was an agreement to use this book in calculating the delivered price quotations. It found further that the Institute established a classification of buyers with a determined discount allowable to each class.

The Commission found that the freight equalization plan was used pursuant to an agreement or understanding and was the device used to carry out a conspiracy to fix and maintain delivered prices. These findings were based upon a showing of the existence of the system and the several joint activities which were employed to facilitate and carry it out. Here again, however, as in the Maltsters case, the

${ }^{31}$ United States Maltsters Ass'n v. Federal Trade Comm'n, 152 F. 2d I6r, I62 (C. C. A. 7th I945); Section 45(c) of the Federal Trade Commission Act provides: "The findings of the Commission as to the facts, if supported by evidence, shall be conclusive." 38 STat. 7I9 (I9I4), as amended, 52 STAT. III (1938), 15 U. S. C. $\$ 45$ et seg. (1946).

The courts have described the quantum and quality of evidence necessary to support the Commission's findings in such a way that there is confusion as to just what evidence is required. It is useless, however, to speculate as to the theoretical differences of these varying descriptions, and space limitations forbid an extended examination of the cases. It does seem safe to say that the Supreme Court is displaying in these delivered price cases a greater respect for the "expertness" of the Commission, and its findings are apt to be conclusive unless clearly arbitrary and unreasonable.

32 "We are of the view that the Commission's findings that a price fixing agreement existed must be accepted. Any other conclusion would do violence to common sense and the realities of the situation. The fact that petitioners utilized a system which enabled them to deliver malt at every point of destination at exactly the same price is a persuasive circumstance in itself." United States Maltsters Ass'n v. Federal Trade Comm'n, I52 F. 2d I61, I64 (C. C. A. 7th I945).

${ }^{33}$ See note 8 supra.

${ }^{34} \mathrm{Milk}$ and Ice Cream Can Institute v. Federal Trade Comm'n, I52 F. 2d 478 (C. C. A. 7th 1946). 
language of the court could be interpreted to mean that conspiracy could be proved by showing merely that the pricing system was in use and produced identical delivered prices. ${ }^{35}$

The next basing point case to reach the courts on review has occasioned more comment than all the others combined. It has put the delivered price problem on the front page, and into the thoughts of most American businessmen, and was the principal reason for the launching of the Congressional investigation of the delivered price problem. ${ }^{36}$ This, of course, is the Cement case. ${ }^{37}$

In 1937 the Federal Trade Commission filed a complaint against the seventy-five major cement manufacturers and their trade association, the Cement Institute, charging that the respondents had restrained and hindered competition in the sale and distribution of cement by means of a combination among themselves made effective through the mutual understanding or agreement to employ a multiple basing point system of pricing. This was alleged to be an unfair method of competition in violation of Section 5 of the Federal Trade Commission Act, and to result in systematic price discriminations between the customers of each respondent in violation of Section 2 of the amended Clayton Act. The Commission found that these charges were supported by competent evidence and issued its cease and desist order in r943, which ordered respondents to cease and desist from "carrying out any planned common course of action, understanding, agreement, combination or conspiracy"38 to do certain things. The Commission contended that these things had to be restrained to restore individual freedom of action among the different units in the cement industry.

The Commission's order was vacated in 1946 by the United States Court of Appeals for the Seventh Circuit. ${ }^{39}$ The Supreme Court granted certiorari in March, I947, and in April, 1948, handed down its decision reversing the circuit court and affirming the order of the Federal Trade Commission. For the present we shall consider only the first count of the Commission's complaint: that charging violation of Section 5 of the Federal Trade Commission Act.

The action of the seventh circuit court is all the more surprising when it is recalled that this is the same court that decided the Maltsters and Ice Cream Can

\footnotetext{
35 "On the face of the situation, it taxes our credulity to believe as argued that petitioncrs cmployed the system without any agreement or plan among themselves." Id. at 482 . "The mere fact that the situation did exist in and of itself furnishes strong support that the Institute and its members were acting cooperatively and by agreement." Id. at 487 .

Mr. Lynn C. Paulson, Assistant Chief Trial Counsel of the F. T. C., pointed this out in his testimony before a Senate Committee:

"Senator, I think we have been injured a time or two by voluntary statements from various courts. They have volunteered in the Milk Can case and the Crepe Paper case, saying this would be conspiracy whether or not there were any facts. We haven't proceeded on that basis. We have always gone to the facts and have not needed or have not used voluntary statements by the courts." Hearings, stupra note 13 , at 122 .

${ }^{3 e}$ S. Res. 24I, 8oth Cong., 2d Sess. (1948).

${ }^{37}$ Federal Trade Comm'n v. Cement Institute, 333 U. S. 683 (1948).

s8 37 F. T. C. $87,258-266$ (1943).

${ }^{39} 157$ F. 2 d 533 (C. C. A. 7 th 1946 ).
} 
cases, the same judge (Major) writing the majority opinion in this and the other two cases. This court held that there was not sufficient evidence to support a Commission finding of a combination among the respondents to restrain competition in price as was charged in both counts of the complaint. Doubt was expressed that the findings of the Commission would support the charge of combination even if supported by sufficient evidence in the record.

In attempting to distinguish this case from the Maltsters and Ice Cream Can cases the circuit court revealed that it saw nothing illegal in an agreement to employ a basing point system, and that it failed to realize that in these prior cases the Commission's findings of conspiracy to fix prices were based upon its belief that concerted adherence to a formula which produced identical delivered prices was a conspiracy to fix and maintain prices. ${ }^{40}$

The dissenting judge in the circuit court recognized that the Commission's charge was directed against agreed-upon use of the basing point system. ${ }^{41} \mathrm{He}$ also felt that the majority opinion deviated from the court's prior decisions on the subject and that the majority was forgetting that the Commission and not the court was the fact finder.

The Supreme Court, in reviewing the case, first overruled the respondents' contentions that the Federal Trade Commission Act did not embrace violations of the Sherman Act, ${ }^{42}$ and then found that the Commission had made adequate findings of a combination to utilize the basing point system as a means of suppressing price competition. $^{43}$ As to the sufficiency of these findings, the Court remarked:44

10 "The Commission also relies strongly upon the recent decisions of this court in U. S. Maltsters Ass'n v. F. T. C., and Milk and Ice Cream Can Institute v. F. T. C., in support of its contention that identical delivered prices are evidence of conspiracy or concerted action. We need not discuss these decisions any further than to point out that in each of those cases a conspiracy to fix prices was charged and found. The multiple basing point price system was not directly involved in either case. In other words, the conspiracy was to fix prices and not merely to use a system from which uniformity of prices resulted, as in the instant case and the old Cement case." Id. at 572.

11 "The Commission's challenge here lays stress on the agreement to utilize a multiple basing point system per se and its order is correspondingly limited to such asserted illegal agreement." Id. at 575 (Judge Evans dissenting).

${ }^{2}$ See note I2 supra.

43 "The Commission's findings of fact set out at great length and with painstaking detail numerous concerted activities carried on in order to make the multiple basing point system work in such a way that competition in quality, price and terms of sale of cement would be nonexistent, and that uniform prices, job contracts, discounts, and terms of sale would be continuously maintained. The Commission found that many of these activities were carried on by the Cement Institute, the industry's unincorporated trade association, and that in other instances the activities were under the immediate control of groups of respondents. Among the collective methods used to accomplish these purposes, according to the findings, were boycotts; discharge of uncooperative employees; organized opposition to the erection of new cement plants; selling cement in a recalcitrant price cutter's sales territory at a price so low that the recalcitrant was forced to adhere to the established basing point prices; discouraging the shipment of cement by truck or barge; and preparing and distributing freight rate books which provided respondents with similar figures to use as actual or 'phantom freight' factors, thus guaranteeing that their delivered prices (base prices plus freight factors) would be identical on all sales whether made to individual purchasers or under sealed bids. These are but a few of the many activities of respondents which the Commission found to have been done in combination to reduce or destroy price competition in cement." 333 U. S. 683, 709-710 (r948).

14 Id. at 712. 
It seems impossible to conceive that anyone reading these findings in their entirety could doubt that the Commission found that respondents collectively maintained a multiple basing point delivered price system for the purpose of suppressing competition in cement sales.

The Court also overruled respondents' contention that the Commission's finding of combination was not supported by substantial evidence. In so doing the Court pointed to the many practices engaged in by the respondents to facilitate and maintain the basing point system, such as the boycotting of dealers who sold imported cement, pledges by producers not to sell f.o.b. plant, and the establishment of a punitive basing point to punish recalcitrants, and observed: $:^{45}$

The Commission was authorized to find understanding, express or implied, from evidence that the Industry's Institute actively worked, in cooperation with various of its members, to maintain the multiple basing point delivered price system; that this pricing system is calculated to produce, and has produced, uniform prices and terms of sale throughout the country; and that all of the respondents have sold their cement substantially in accord with the pattern required by the multiple basing point system.

This is a direct approval by the Supreme Court of the Commission's method of proving a concerted use of the basing point system, that is, proof of the use of the system and of the various practices which are always employed to maintain the system. This is, it is true, not a holding that such a system is illegal per se, but since it is very unlikely that such a system could be maintained among several sellers without the use of at least some of these cooperative implementations, ${ }^{40}$ the system when so used will probably be unable to withstand a charge of conspiracy.

As to the legality of a conspiracy or agreement to use the multiple basing point system the Court had this to say $:^{4 \pi}$

We sustain the Commission's holding that concerted maintenance of the basing point delivered price system is an unfair method of competition prohibited by the Federal Trade Commission Act.

The Court then added a statement which, although admittedly dictum, might well prove to be its most important pronouncement in the entire case, particularly in view of the next case which we shall consider $:^{48}$

While we hold that the Commission's findings of combination were supported by evidence, that does not mean that existence of a "combination" is an indispensable ingredient for an unfair method of competition under the Trade Commission Act.

45 Id. at $7 \mathrm{I} 6$.

66 "It is conceivable that a basing-point cartel may function without any visible tools or gadgets, without any trace of patently collusive acts, without any 'cartel organs' aiding the obscrvance of unwritten 'cartel rules.' Theoretically, the publication of base prices by the basing point mills is the only indispensable device for the operation of the system. This, however, is not likely to work in practice, at least not over a long period." F. Machlup, The Basing Point System 20 (1948).

"This is particularly apparent as to basing point systems, which seem necessarily to require collusion, either in outright form or in 'parallel action' of a sort which will not withstand the inference of collusion." Wright, Collussion and Parallel Action in Delivcred Price Systems, 37 Geo. L. J. 201, 213 (1948).

" 333 U. S. 683,720 (1948).

${ }^{43}$ Id. at $72 \pi$. 
Justice Burton wrote a dissenting opinion very similar to the majority opinion in the circuit court.

The Conduit case ${ }^{49}$ was the next basing point proceeding to be reviewed by the courts. The petitioners were fourteen manufacturers of rigid steel conduit who sought to have set aside a cease and desist order of the Federal Trade Commission based upon a complaint in two counts, which charged a collective violation by the petitioners and their trade association, the Rigid Steel Conduit Association, of Section 5 of the Federal Trade Commission Act.

The first count alleged that petitioners were engaged in a conspiracy whose purpose and effect was to restrict and suppress actual and potential competition in the distribution and sale of rigid steel conduit in commerce, and which was effectuated by the adoption and use of a basing point method of quoting prices. This count is similar to the first count in the Cement case and was sustained by the Commission upon evidence much like that adduced in that case. The use of the system and the various cooperative practices employed to maintain it were shown. The principal implementation activities were compilation of freight adders to insure identical delivered price quotations, classification of customers and establishment of differentials between them, adoption of uniform contracts, and investigations to enforce compliance with such contracts. The court said that there was direct proof of the conspiracy but even if there was not, "in determining if such a finding is supported it is not necessary that there be direct proof of an agreement. Such an agreement may be shown by circumstantial evidence." ${ }^{.50}$

The second count did not depend upon combination or conspiracy. It charged that each respondent with knowledge that the other respondents did likewise, refrained from quoting f.o.b. prices, but computed prices by use of the basing point formula which resulted in a price made up of the published price plus freight adders from one or more basing points, despite the fact that shipment might actually be made from some other point from which some other freight factor might actually apply. Uniformity in the delivered prices of respondents at a given destination was alleged to be "inherent in, and a necessary result of, such method or system of basing-point-delivered-price quotations." ${ }^{\text {. } 1 ~}$

It was alleged further that respondents habitually charged their customers located near their plant a higher price than those located at a distance, thus forcing the nearby customers to pay more and the customers at a distance "within and without a particular basing point area to pay less, than would otherwise be the case, thus depriving the nearby customers of each said respondent 'conduit seller' of price advantages which they would naturally enjoy by reason of their proximity to points of production." ${ }^{\text {.52 }}$

${ }^{60}$ Triangle Conduit and Cable Co. v. Federal Trade Comm'n, I68 F. 2d I75 (C. C. A. 7th 1948), aff'd per curiam sub nom. Clayton Mark \& Co. v. Federal Trade Comm'n, 336 U. S. 956 (1949).

${ }_{50} 168$ F. $2 d \times 75,180$ (C. C. A. 7 th 1948 ).

"2 Rigid Steel Conduit Ass'n, 38 F. T. C. 534, $55^{\circ}$ (1944).

${ }^{62} \mathrm{Ibjd}$. 
The Commission found that the use of the basing point system produced the results alleged ${ }^{53}$ and concluded that these acts and practices constituted unfair methods of competition in violation of Section 5 of the Federal Trade Commission Act.

The court, in considering the second count, pointed out the conscious parallel use of the basing point formula, the matching of prices, and the systematic variations in mill nets of the sellers, and said: ${ }^{54}$

Each seller consciously intends not to attempt the exclusion of any competitor from his natural freight advantage territory by reducing the price, and in effect invites the others to share the available business at matched prices in his natural market in return for a reciprocal invitation.

It then stated that the legal issue presented was the same as in the Cement case; referred to the Supreme Court's dictum that a combination is not necessary to the finding of an unfair method of competition; and concluded, "In the light of that opinion, we cannot say that the Commission was wrong in concluding that the individual use of the basing point method as here used does constitute an unfair method of competition."55

The Supreme Court affirmed the decision of the circuit court, but unfortunately without any written opinion. ${ }^{56}$

There has been much discussion and some dispute as to the meaning and breadth of the court's holding on the second count in this case. Some seem to think that the phrase "as here used" means that the Court never really passed upon the legality of an individual use of the system with knowledge that others are using it, and that the holding is based upon conspiracy or collusion. ${ }^{57}$

The Federal Trade Commission itself has issued several statements on the meaning of the Conduit case. In one press release the Commission interpreted the case as holding the basing point method of pricing to be an unfair method of competition regardless of conspiracy.8 ${ }^{58}$ On October 12 , 1948, the Commission issued a statement of policy designed to explain and further clarify the law which pointed

ss The Commission also found: "That the capacity, tendency, and effect of the use by each respondent named therein of the basing point delivered-price formula to determine price quotations and prices which will be made to conduit purchasers at any given destination concurrently with similar use of the same pricing formula by other of the said respondents has been, and is, to hinder, lessen, and restrain competition in price in the sale and distribution of conduit; to deprive purchasers of the benefits of competition; to create in each of said respondents a dangerous tendency toward a monopolistic control over price in the sale and distribution of conduit." Id. at 593.

I4 168 F. 2d 175, I8I (C. C. A. 7 th 1948 ).

55 Ibid. (Italics supplied.)

${ }^{56} 336$ U. S. 956 (I949).

67 'I think if I were advising a client I would say 'as here used,' and that means pursuant to a combination and conspiracy. I think I would take that gamble if I were advising a client. That remains to be settled, I think." Lynn C. Paulson, Ass't Chief Trial Counsel, F. T. C., Hearings, supra note 13 , at 241 .

s8 "Use of a basing point system of delivered prices by individual companies, engaged in the production and sale of rigid steel conduit, with knowledge that other sellers are using the same pricing methods and with the result that price competition is unreasonably restrained constitutes an "unfair method of competition' in violation of the Federal Trade Commission Act irrespective of any combination or conspiracy." F. T. C. Press Release, May I9, 1948. 
out that, although the Commission thought that the economic results flowing from a number of sellers following a parallel course of action were the same as those flowing from a combination or conspiracy, it did not base its Count II upon any combination or conspiracy..$^{59}$

It seems quite clear therefore that the Commission did not rely upon combination or conspiracy under Count II. In fact it was careful to point out in its brief that it did not do so, saying $:^{.0}$

Under Count II the issue is simply whether the concurrent use of the basing point practice-constitutes ... an unfair method of competition within the meaning of Section 5 of the Federal Trade Commission Act.

In still another place in its brief the Commission stated: ${ }^{61}$

Count II and a corresponding part of the order are frankly directed against the basing point practice as being per se an unfair method of competition, even though not predicated on combination and conspiracy.

In fact, to construe this second count of the case as based upon the conspiracy found under the first count is to make it meaningless and mere surplusage.

This is the second instance, the Pittsburgh Plus case being the first, in which the Commission has found that where there is common use of the basing point system in an industry, each seller's adherence to and employment of the system is an unfair method of competition. This finding is based upon the realization that common and reciprocal use of a basing point system, whether induced by agreement, price leadership, or what not, produces the same economic results and has the same destructive effects upon price competition. ${ }^{62}$ That the count was phrased in this way, instead of charging conspiracy or combination, illustrates also the Commission's belief that it had need for this type of complaint in order to secure effective relief from the collusive conduct proved in the first count. ${ }^{63}$

so "In the Rigid Steel Conduit case, the Commission found, and the circuit court agreed, that adherence to an industry-wide basing point formula, with the knowledge that other concerns are adhering to it also constitutes in itself a violation of the Federal Trade Commission Act by the individual adhering companies when price competition is thereby eliminated. It would have been possible to describe this state of facts as a price fixing conspiracy on the principle that when a number of enterprises follow a parallel course of action in the knowledge and contemplation of the fact that all are acting alike, they have in effect, formed an agreement. Instead of phrasing its charge in this way, the Commission chose to rely on the obvious fact that the economic effect of identical prices achicved through conscious parallel action is the same as that of similar prices achieved through overt collusion, and, for this reason, the Commission treated the conscious parallelism of action as a violation of the Federal Trade Commission Act." FTC, Statement of Policy, supra note 8.

${ }^{\circ 0}$ Brief for F. T. C., Triangle Conduit and Cable Co. v. Federal Trade Comm'n, I68 F. 2d I75 (C. C. A. $7^{\text {th }}$ 1948).

${ }^{\circ}$ Ibid.

02 "Even this charge rests upon a concert of action which brings about an economic effect indistinguishable from the collusion which is also charged in the same complaints." Corwin D. Edwards, stipra note $2 \mathrm{I}$.

o3 "It prohibits them from continuing the same kind of practice that they had formerly continued by means of a conspiracy. . . . It is founded basically upon the proved and established injury to the competition in the past and upon the practically certain continuation of that injury in the future." W. B. Wooden, Associate General Counsel and Chief, Division of Appellate Proceedings, F. T. C., Hearings, stipra note 13 , at 695 . 
Although the second count is not based upon combination or collusion but upon conscious parallelism of action, the principle developed will probably have application only in situations in which actual conspiracy could be proved. Consequently, its principles have no application to the question of the legality of the independent use of the basing point system by a single seller, or the legality of such seller's practice of absorbing freight. ${ }^{64}$

The Commission bases its method of proceeding under this second count primarily upon the Beech-nut case, ${ }^{65}$ and upon the dictum in the Cement case that combination is not necessary to an unfair method of competition within the meaning of the Federal Trade Commission Act. In the Beech-nut case the Court upheld the Commission's order against the respondent's price-maintenance policy-because of its tendency unduly to hinder competition or create monopoly even though the complaint was not based upon combination or collusion. ${ }^{68}$ In this case, however, there was evidence adduced from which an actual agreement probably could have been inferred. It is, therefore, somewhat misleading to attempt to support the conscious parallelism of action theory of the second count by means of the Beechnut case. Likewise, the principle that combination or conspiracy is not necessary to a Federal Trade Commission Act violation lacks specific meaning unless examined in the light of those cases in which it was developed.

Despite these weaknesses in the Federal Trade Commission's case against conscious parallelism of action, the sustaining of its arguments by both the circuit court of appeals and the Supreme Court would seem to be a vindication of its position. This conclusion is somewhat weakened, however, when we recall that the circuit court erroneously assumed that the issue to be decided in the Conduit case was identical with that decided in the Cement case, and that the Supreme Court did not hand down an opinion in the case because of the disqualification of one justice and the equal division of the others, but merely affirmed the circuit court's decision per curiam.

The force of the second count of the Conduit case is weakened even further by later statements of the Federal Trade Commission made under the pressure of a Congressional investigation. The Commission now seems willing to consider the second count of the Conduit case as simply a special remedy needed in this particular instance to secure effective relief from the conspiracy, ${ }^{67}$ and appears ready to abandon

os "Under the Federal Trade Commission Act, where there is neither conscious parallel action which eliminates price competition nor monopolistic position maintained through unfair methods, a single enterprise is free to adopt any geographic pricing practice." FTC, STATEMrent of Policy, supra note 8.

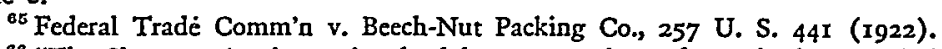

oo "The Sherman Act is not involved here except in so far as it shows a declaration of public policy to be considered in determining what are unfair methods of competition, which the Federal Trade Commission is empowered to condemn and suppress. . . . If the Beechnut system of merchandising is against public policy, because of 'its dangerous tendency unduly to hinder competition or to create monopoly,' it was within the power of the Commission to make an order forbidding its continuation." Id. at 453 .

${ }^{67}$ Hearings before Subcommittee of Senate Judiciary Committee on S. 1008, 81st Cong., Ist Sess. 70 (1949). 
its position on conscious parallelism of action as argued before the courts and espoused in its statement of policy. ${ }^{88}$

This seeming change in position by the Federal Trade Commission will not make the practice of basing point pricing any safer, however, as the Commission can, and undoubtedly will, continue to attack the system under the Federal Trade Commission Act by proving collusion in its adoption or use, or by showing that it is used to implement an agreement on prices. As was pointed out above, an analysis of the operation itself generally provides evidence that will be accepted by the Commission and the courts as sufficient to sustain a finding of collusion in the adoption or maintenance of the system. If the system cannot operate without these tell-tale signs of conspiracy, the Commission can successfully proceed against its common and collective use without resort to the conscious parallelism of action theory.

The most recent basing point case to reach the courts demonstrates very well the Commission's ability to proceed successfully against such a use of the system as being a conspiracy in restraint of trade. In Bond Crown \& Cork Co. v. Federal Trade Commission, ${ }^{69}$ the respondent manufacturers of bottle crowns and their trade association, the Crown Manufacturers Association of America, petitioned to have reviewed and set aside an order of the Federal Trade Commission finding that they were engaged in a conspiracy and combination in restraint of trade which was an unfair method of competition in violation of the Federal Trade Commission Act.

The evidence which the Commission held supported such a finding and order was ( $\mathrm{I}$ ) the use of a freight equalization system resulting in identical prices of all sellers at any given delivery point, (2) rigidity in the price of crowns since $193^{8}$, (3) standardization of crowns through the Association, (4) adherence to the terms of a standard sales contract which was discussed before the Association in ig20 but never formally adopted, (5) patent license agreements between the largest manufacturer in the industry and other manufacturers, which contained a minimum price clause until shortly before institution of the proceedings by the Commission, and (6) the furnishing of price information to these licensees by the licensor.

The circuit court in affirming the Commission's order paid great deference to the "expertness" of the Commission and its power to infer conspiracy from such circumstantial evidence. The court seemed particularly impressed by the evidence as to price uniformity and rigidity, and that as to standardization of product. ${ }^{70}$

${ }^{\circ 8}$ See notes 59,60 , and $6 x$ supra.

176 F. 2 d 974 (C. C. A. 4 th 1949 ).

70 "We conclude the discussion on the sufficiency of the evidence by adverting again to the indisputable fact that through the business practices followed by petitioners it has resulted that in an industry of which they control 85 per cent there has been no price change in ten years and absolutely no price competition whatever. The product has been so standardized that there is no choice of any sort between the products of different producers, and a purchaser anywhere in the country can purchase at the same price including freight from any producer. It is argued that all this is the result of the free play of economic forces, but the Commission did not think so; and this is just the sort of question that Congress intended the Commission to decide." Id. at $98 \mathrm{I}$. 
In this case the evidence introduced in addition to that as to the bare existence of the delivered price system was less than in any prior case. Both the Commission and the court placed great emphasis upon inherent features of the system itself. It is submitted that it is virtually impossible for several members of an industry to employ a basing point system of pricing without leaving a trail of evidence such as was accepted by the Commission and the courts in this case, and to a lesser extent in prior cases, as sufficient to prove an unlawful conspiracy in restraint of trade.

The Federal Trade Commission also has proceeded against the zone system where it is used as a price fixing device. In most of these proceedings there was no petition for court review. Between 1936 and 1938 the Commission proceeded against conspiracies to fix prices by means of zone systems in seven cases involving as many industries. ${ }^{71}$ In each of these cases the allegations of the complaint were admitted or the facts were stipulated and a consent decree entered.

The first of such orders to be contested before the Commission and on review was Scientific Apparatus Makers of America. ${ }^{72}$ It was found by the Commission that the zone system had been adopted pursuant to agreement and that there was an agreement to follow a price list that was circulated among the respondent blue print paper producers. These findings were upheld by the court of appeals on review. ${ }^{73}$ The most important aspect of the case was that concerning the liability of two of the producers who had not joined in the original conspiracy, but who later followed the price system set up by the conspirators. As to them the court held : ${ }^{74}$

One may be liable regardless of when he joins the unlawful trade practices. ... We do not think that affirmative, positive express agreement to maintain prices is essential to establish unfair trade practices. If the parties clearly and intentionally maintain the prices, even though without express agreement they are liable. ... An artificial price level not related to the supply and demand in a given commodity, may evidence concerted action of sellers operating to restrain commerce. That is what the evidence here shows.

The fact that actual agreement to adopt the system and fix the prices was shown had great influence upon the decision as to these two respondents; nevertheless, this case shows that the courts are willing to go a long way toward inferring concerted action from the mere use of a zone system. It of course also demonstrates that adherence to a system founded by agreement will be held illegal even though such adherence is not pursuant to agreement or combination.

\footnotetext{
${ }^{71}$ The Water Works Valve and Hydrant Group of the Valve and Fittings Institute, 24 F. T. C. 1253 (1937); Menasha Wooden Ware Corporation, 25 F. T. C. 57 (1937); United Fence Manufacturers Ass'n, 27 F. T. C. 377 (1938); Food Dish Associates of America, 27 F. T. C. 1267 (1938); Columbia Alkali Corporation, 27 F. T. C. 1354 (1938); Rowe Manufacturing Company, 27 F. T. C. I376 (1938); Mathieson Alkali Works, Inc., 27 F. T. C. 1413 (I938).

${ }^{2} 33$ F. T. C. II30 (I94I).

${ }^{73}$ Eugene Dietzgen Co. v. Federal Trade Comm'n, I42 F. 2 d 321 (C. C. A. $7^{\text {th }}$ I944).

${ }^{76}$ Id. at $33 \mathrm{r}, 332$.
} 
An early attempt to eliminate the need for proof of conspiracy in enforcing its orders against zone systems was made by the Commission in Salt Producers Association v. Federal Trade Commission. ${ }^{75}$ The complaint ran against eighteen salt companies and the Salt Producers Association and charged a combination to monopolize and suppress competition in the sale of salt, to fix unfair prices, and to establish zones to aid in fixing of prices, etc. The respondents admitted the allegations of the complaint but objected to the terms of the order which ordered respondents to cease and desist from participating in "any common course of action, mutual agreement, combination or conspiracy, to fix or maintain the prices of salt" and from "establishing or maintaining delivered price zones, or making quotations and sales of salt upon a delivered price basis under a zone system whereby the cost of salt delivered to buyers within each respective zone is made identical at all destinations within such zone." "76

The respondents objected strenuously to the inclusion of the phrase "common course of action" in the order, contending that it would include common action occurring through pure happenstance. The Commission, on the other hand, contended that it did not apply to independent action "undertaken independently without previous agreement therefor." The court reasoned that since the Commission intended only to accomplish the prohibition of planned mutual action it would be fair to add "planned" before the disputed phrase.

The respondents also objected to the order's prohibition of the establishment of uniform prices for specified zone areas and asked that individual sellers be allowed to utilize the zone method of pricing. The court remarked that it was the Commission's aim only to eliminate all concert of action, and that the complaint did not show an attack upon the zone system per se as an unfair method of competition by one manufacturer in relation to two of his customers, and concluded that the respondents should not be denied all right to use of the zone method of pricing.

It seems that here the Commission was attempting to accomplish with respect to zone systems what it accomplished with respect to the basing point system in the second count of the Conduit case. It failed because its complaint was directed solely at combination or conspiracy, and because it made no determination of the unfairness of the system when used by one manufacturer in such a situation. In the Conduit case the Commission remedied both of these deficiencies by alleging that knowing parallel use of the basing point system was an unfair method of competition, and that the individual manufacturer in such circumstances discriminated against his nearby purchasers.

The principle of the second count of the Conduit case is undoubtedly equally applicable to the parallel use of the zone system by a number of sellers.

${ }^{75} \times 34$ F. 2 d 354 (C. C. A. 7th 1943).

${ }^{70} 34$ F. T. C. 38 (194I). 
The zone system case which has prompted the most discussion and controversy is Fort Howard Paper Co. v. Federal Trade Commission. ${ }^{77}$ Involved were a trade association, and eight corporations who were members, or had been members, of the trade association, and who comprised all the manufacturers of crepe paper in the United States. The respondents were charged with being engaged in a "conspiracy, combination, agreement, and understanding for the purpose and with the effect of restricting, restraining, suppressing and eliminating price competition among respondent manufacturers in the sale of crepe paper in commerce. . ..78

There was some evidence of a price fixing agreement under the N.I.R.A. and of its continuation after the N.I.R.A. was invalidated. The bulk of the evidence, however, consisted of a showing of the existence and use of the zone pricing system and the cooperative trade practices, such as classification of customers, uniform product standards, and filing of price lists with the association, which were followed in order to facilitate and maintain the system. From this evidence the Commission found that the zone system was cooperatively adopted and maintained and hence was the device used to set up and maintain uniform prices for the sale of crepe paper.

The court upheld the Commission's findings and, as in the Milk Can case, placed much more emphasis upon the significance of the identical delivered prices than did the Commission, ${ }^{\mathbf{7 9}}$ and glossed over the many trade practices upon which the Commission relied to prove conspiracy. ${ }^{80}$ The court by its opinion intimates that it would uphold an inference of conspiracy drawn from the bare industry-wide use of the zone pricing system. ${ }^{81}$

Although there has never been an attack upon the legality of a zone pricing system per se, in view of these recent cases it now seems quite likely that where it is used by a number of sellers in a given industry so that the customer is faced with identical delivered prices at all points, it will be unable to withstand an inference of conspiracy, except perhaps in the few instances in which the identity of prices may be explainable by the nature of the market, the type of product, or the transportation costs. ${ }^{82}$ The recent tendency of the courts to emphasize and give great weight to the "expertness" of the Federal Trade Commission, as exemplified in the Crown case, greatly reenforces this conclusion. And, as pointed out with respect to the basing point system, the apparent abandonment of the conscious parallelism

${ }^{77}$ I56 F. 2 d 899 (C. C. A. 7 th 1946 ).

${ }^{78} 38$ F. T. C. 282,283 (1944).

${ }^{79}$ See note 35 stipra. See also, Allied Paper Mills v. Federal Trade Comm'n, 168 F. $2 d 175$ (C. C. A. $7^{\text {th }} \mathrm{r948}$ ), cert. denied, 336 U. S. 918 (1949).

so "We think the artificiality and arbitrariness of the zone structure is so apparent it cannot withstand the inference of agreement. The Commission evidently could not believe that Wisconsin companics would deprive themselves of the natural benefit of location in the midwest, and proximity to the west, over eastern competitors, were it not agreed that they would have equal chance for the castern business, where most of the crepe paper manufacturers were located. I56 F. 2d 899, 907 (C. C. A. 7th 1946).

${ }^{81}$ See Wooden, The Defense of Delivered Price Systems, I5 Geo. WAst. L. Rev. I, 27 (1946).

82 "When a group of competing sellers have all chosen to establish an unnatural zone system with identical boundaries and identical price differentials, it is difficult to believe that this result could be achieved and maintained without collusion." FTC, Statement of Policy, stipra note 8. 
of action theory by the Commission will not render the Commission any less capable of successfully proceeding against the common or parallel use of a zone system on the ground of collusion in its adoption or use.

Although the Commission has never proceeded against the one zone price system, its proceedings against the multiple zone system indicate that where the prices of a number of sellers following such system are identical to such a degree that there is reflected the absence of an independent and individual determination to adopt them, this system will likewise be unable to withstand an inference of collusion and will be held illegal as an unfair method of competition under Section 5 of the Federal Trade Commission Act.

To the extent that the individual adoption and use of the one zone system is predicated upon a sincere desire to sell competitively in a nationwide market, the system will be immune from attack under the Federal Trade Commission Act. Consequently, the seller who wishes to use a one zone pricing system in order to exploit a nationally advertised brand may do so without fear of prosecution under the Federal Trade Commission Act if his price is independently determined. The frequently expressed fear that the Commission will mistake independently arrived at prices for conspiracy prices and succeed in convincing the courts of the validity of such findings seems unfounded.

These cases under the Federal Trade Commission Act are all based upon concerted or collective use of the delivered pricing systems and have little, if any, application to the problems arising from the individual and independent use of such systems. ${ }^{83}$ Proceedings against individual and independent use of any of the delivered pricing systems have been had only under the Clayton Act as amended by the Robinson-Patman Act, and the number of such proceedings under that Act is very small.

\section{IV}

The Cuayton Act as Amended by the Robinson-Patman Act of 1936

The price discrimination elements in delivered price systems expose them to findings of illegality under the Clayton Act as amended by the Robinson-Patman Act. It is this aspect of the delivered price problem that has resulted in the most confusion and in the most controversy over the legality of the various systems.

This confusion and controversy may result from the attempt to apply a somewhat vague and poorly drafted statute to a variety of exceedingly complex business situations involving economic aspects which are little understood. It may reflect the natural reluctance of businessmen to give up a way of doing business that not only has proved lucrative, but also has helped to relax some of the rigors of competition which, although perhaps necessary to the preservation of the free enterprise system, have been to businessmen an evil to be avoided if possible. Perhaps it is a reflection of the unwillingness of some of the dominant figures of our

\footnotetext{
${ }^{83}$ See note 64 stipra.
} 
economy to give up some of the means which they have used to inflict their wishes upon their weaker competitors so as to enhance and perpetuate their own power and control. These and many other assertions are made in any discussion of the problem, and an economic theory can be found to fit every argument pro and con on this subject.

My purpose here is not to reconcile these economic arguments nor to criticize the Robinson-Patman Act or its enforcement by the Federal Trade Commission, but to set forth the present legal status of delivered price systems under the Act. Since the cases are not numerous, much emphasis is given to policy statements of the Federal Trade Commission, and there is of necessity much reference to material in the decided cases which admittedly is dictum.

The purpose of the Robinson-Patman Act was to amend Section 2 of the Clayton Act, which prohibited price discriminations in interstate commerce whose effect "may be to substantially lessen competition or tend to create a monopoly in any line of commerce." Although the Clayton Act was passed in 19r4, it was not until I930 that it was definitely decided that the Act applied to competition among the customers of the seller as well as to competition between the seller and his competitors. ${ }^{84}$ Until that time the Act had been given a narrow construction to include only competition between the seller and his own competitors. ${ }^{85}$

One of the principal criticisms of the original Clayton Act was that it was too restrictive in requiring a showing of injury to general competitive conditions in the affected line of commerce, while the more important problem should be the injury to the competition of the person upon whom the discrimination was practiced. ${ }^{86}$

The Robinson-Patman Act was designed to eliminate this "weakness." So Section 2(a) of the new Act carried over the basic provisions of Section 2 of the Clayton Act with the added provision as to injury of competition with the individual seller or his customers and the customers of such customers. The basic provisions of the Clayton Act were not changed, and the Congressional intent seems to have been to continue the interpretation given to them under the original Act. ${ }^{87}$ Section 2(a) provides in part:

That it shall be unlawful for any person engaged in commerce, in the course of such commerce, either directly or indirectly to discriminate in price between different purchasers of commodities of like grade and quality, where either or any of the purchasers involved in such discrimination are in commerce, where such commodities are sold for use, consumption, or resale within the United States or any territory thereof or the Dis-

${ }^{84}$ George Van Camp and Sons Co. v. American Can Co., 278 U. S. 245 (1930).

${ }^{85}$ Mennen and Co. v. Federal Trade Comm'n, 288 Fed. 774 (C. C. A. $2 d$ 1923).

${ }^{86}$ H. R. REP. No. 2287, 74th Cong., 2d Sess. 8 (1936); American Can Co. v. Ladoga Canning Co., 44 F. 2 d 763,766 (C. C. A. $7^{\text {th }}$ 1930), cert. denied, 282 U. S. 899 (193I).

${ }^{87}$ Representative Utterback stated that these provisions "correspond to those required to be shown under the old Section 2 of the Clayton Act. Generally speaking they require a showing of effect upon competitive conditions generally in the line of commerce and market territory concerned as distinguished from the effect of discrimination upon immediate competition with the grantor or grantec." 80 Cong. Rec. 9417 (I936). 
trict of Columbia or any insular possession or other place under the jurisdiction of the United States and where the effect of such discrimination may be substantially to lessen competition or tend to create a monopoly in any line of commerce, or to injure, destroy, or prevent competition with any person who either grants or knowingly receives the benefit of them: Provided, That nothing herein contained shall prevent differentials which make only due allowance for differences in the cost of manufacture, sale or delivery resulting from the differing methods or quantities in which such commodities are to such purchasers sold or delivered.

No question can arise under this section of the statute unless there is a discrimination in price. The statute nowhere defines what is meant by discrimination, although it implies at least a difference in price. ${ }^{88}$ It is important to note also that this discrimination or difference is not unlawful unless its effect "may be" that which is set out in the statute.

Since a difference in price is essential to illegal action under the statute, it becomes important to know how this difference is to be determined. This is particularly important when the application of the Act to delivered price systems is considered. There are two ways in which the difference in price may be determined. One method is to deduct all freight costs from the amount paid by the buyer and examine the net amounts realized at the plant. ${ }^{89}$ If this method is used all forms of delivered pricing except f.o.b. mill pricing without freight equalization must create differences if sales are made at more than one point. Another method is to examine the delivered prices of buyers in different localities. If this method is used differences must exist in all cases of delivered prices except where a one zone system is used. It thus becomes apparent that if only the delivered prices are examined the one zone system cannot violate the Act as it involves no difference in price upon which to base a charge of discrimination.

${ }^{88}$ Representative Utterback, Chairman of the House Managers on the Robinson-Patman Act, in explaining this bill to Congress, had this to say about the meaning of discrimination: "In its meaning in simple English, a discrimination is more than a difference. Underlying the meaning of the word is the idea that some relationship exists between the parties to the discrimination which entitles them to equal treatment, whereby the difference granted to one casts some burden or disadvantage upon the other. If the two are competing in the resale of goods concerned that relation exists." 80 Cong. Rec. $9416(1936)$.

This definition is concerned only with competition in the second line, although the Act speaks of competition in the primary and in the third line. Consequently, we should add to the definition that a difference is discriminatory also which occurs where there are competitive conditions existing between the seller and his competitors and between customers of the purchasers from the seller, or between the customers of the competitors of such purchasers. Actually about all we can say in the way of definition is that for there to be a discrimination there must be a difference in price, but not all differences are necessarily discriminatory.

${ }^{80}$ The Federal Trade Commission sponsored an amendment to the Robinson-Patman Act which provided: "The word price, as used in this Section 2, shall be construed to mean the amount received by the vendor for each commodity unit, after deducting actual freight or cost of other transportation, if any, allowed or defrayed by the vendor." H. R. REP. No. 8442, 74th Cong., 2d Sess. (I936).

The definition was eliminated from the final bill. Representative Citron, of the House Judiciary Committee, stated that it should be dropped because "serious consequences of the inclusion of this definition of price ... would be to compel all manufacturers to ship f.o.b. shipping point." 80 Cong. REc. 8224 (I936).

During the same session Congress considered, but failed to enact, the Wheeler Anti-Basing Point Bill. 80 CoNG. REc. 8102, 8223 (1936). 
The legality of the one zone system may depend then upon which conception of price prevails. The adoption of the "mill net" theory also may expose the uniform delivered prices within the zones of the multiple zone system to findings of discrimination. Basing point, freight equalization, and multiple zone price systems all produce differences in price which may be illegal regardless of which conception is followed.

It has been contended that since a difference in delivery cost does not necessarily result from the different methods or quantities in which the commodities are sold or delivered a difference in price cannot be justified by a showing of difference in delivery cost. ${ }^{90}$ This argument appears valid if judged from a strict grammatical viewpoint. However, the intent of the framers of the Act seems contrary. Representative Utterback, Chairman of the House Managers, in explaining the bill stated: $: 1$

Where the methods of delivery are the same, but the distance is different, price differences in such cases may, of course, be made to reflect those differences.

Moreover, the Federal Trade Commission and the courts have always assumed that such differences may be so justified. This proviso constitutes an affirmative defense to a charge that a price differential is an unlawful discrimination under the Act. It follows that any price difference which does not reflect differences in cost stands unexcused under this proviso and the Commission has taken the position, likewise accepted by the courts, that if it has the effect upon competition contemplated by the statute it is unlawful unless it can be justified under some other provision of the Act. ${ }^{92}$

A further provision of the Act pertinent to our discussion is Section 2(b), ${ }^{03}$ which has given rise to much doubt as to whether the Federal Trade Commission has the burden of showing that a price discrimination has the requisite statutory effect on competition, or whether this burden rests upon the respondent once a difference in price, under circumstances making such difference a discrimination, has been shown. There is also doubt as to whether this section makes the good faith meeting of an equally low price of a competitor a substantive defense.

The use in this section of the terms "prima facie" case and "rebuttal" is largely responsible for the confusion and controversy which exist. On its face the section would seem to authorize the Commission to issue a cease and desist order when it finds that a price discrimination has been practiced. It seems, however, that the

${ }^{\text {so }}$ Hilder, The Attack Upon Delivered Price Systems, 14 Geo. WAstr. L. R. 397, 414 (1946).

9180 Cong. Rec. 94I7 (1936).

${ }^{92}$ See Wooden, supra note 81, at 14.

${ }^{83}$ "Upon proof being made, at any hearing on a complaint under this section that there has been discrimination in price or services or facilities furnished, the burden of rebutting the prima facie case thus made out by showing justification shall be upon the person charged with a violation of this section, and unless justification shall be affirmatively shown, the Commission is authorized to issue an order terminating the discrimination: Provided, however, that nothing herein contained shall prevent a seller rebutting the prima facie case thus made by showing that his lower price or the furnishing of services or facilities to any purchaser or purchasers was made in good faith to mect an equally low price of a competitor, or the services or facilities furnished by a competitor." 
Commission in its early proceedings under the Act never claimed such authority. It always followed its proof of discrimination with proof of the requisite effect on competition. $^{94}$ Then in 1945 in the Moss case, ${ }^{95}$ the Court of Appeals for the Second Circuit raised serious doubts as to the necessity of the Commission's proving the effect upon competition.

In this case the Commission's complaint alleged that the respondent's price discriminations had produced the proscribed effect on competition and the Commission made findings adequate to support this allegation. ${ }^{96}$ Despite this pleading of effect on competition and the affirmative finding directly on that point, the court in reviewing the case stated: ${ }^{97}$

The Commission's position was that, having proved this (price discrimination), Section 2(b) put upon the petitioner the burden of justifying the discrimination, and warranted the order if it failed to do so.

The court then said that it was the Commission's burden to prove a difference in price and that there were competitors who might have been able to meet the higher price but could not meet the lower one. It then pointed out that the burden of proving the harmful effect on competition was difficult: ${ }^{98}$

Hence Congress adopted the common device in such cases of shifting the burden of proof to anyone who sets two prices and who possibly knows why he has done so, and what has been the result. If he can prove that the lower price did not prevent or tend to prevent anyone from taking away the business he will succeed, for the accuser will not have brought him within the statute at all. Nevertheless he may succeed even though he fails to establish such a negative; for although it will then appear that he has lessened, or prevented, competition, the proviso of Section 2(b) will still excuse him, if he can show that his lower price did not undercut his competitors, but merely met their "equally low price." In short that is a defense to the violation of Section 2(a). This is as we interpret Section 2(a) and Section 2(b), when read together.

Thus, we have this court enunciating the rule that the accused has the burden of proving that his discrimination did not affect competition in the manner prohibited by the statute. This, despite the history of the Commission's prior practice and the fact that the Commission actually pleaded and found the proscribed effect on competition in this case.

The Commission was not long in taking advantage of this court's interpretation of the burden of proof, and in attempting to disprove that Section 2(b) provided a substantive defense to a price discrimination which had the proscribed effect upon competition. In October of that same year, I945, the Commission filed its com-

${ }^{\circ}$ See Haslett, Price Discriminations and Their Itstification Under the Robinson Patman Act of 1936, 46 Mrch. L. REv. 450, 474 (I948).

${ }^{05}$ Samuel H. Moss, Inc. v. Federal Trade Comm'n, 148 F. 2 d 378 (C. C. A. $2 d$ 1945), cert. denied, 326 U. S. 734 (1945).

36 F. T. C. 640,649 (I943).

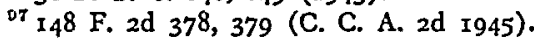

os lbid. 
plaint, findings, and order in the Standard Oil Co. case. ${ }^{99}$ In this case the Commission alleged and made affirmative findings that the respondent sold gasoline to different customers at different prices and that this constituted discriminations in price whose effect "has been and may be to injure, destroy and prevent competition" with the named respondents and "with their respective customers, in the resale of gasoline."

The respondent offered evidence that its lower prices were made to meet the equally low price of competitors but the Commission refused to receive this evidence contending that, even if the lower prices were so made, "This does not constitute a defense in the face of affirmative proof that the effect of the discrimination was to injure, destroy, and prevent competition."100

The Commission's theory of the Section 2(b) defense was set out at great length. Its contention was that a prima facie case was made out by proving (x) jurisdiction, (2) goods of like grade and quality, and (3) discrimination in price. This prima facie case may be rebutted if the respondent can show that his lower price was made in good faith to meet an equally low price of a competitor. This is declared to be not a substantive defense, however, and if the Commission can then show that "the effect of the discrimination may be to substantially lessen competition or tend to create a monopoly or to injure, destroy, or prevent competition between respondent and its competitors or between customers of the respondent or with the customers of such customers," ${ }^{101}$ it has proved an illegal discrimination.

The Commission appears to accept the rule of the Moss case as to the burden of proof and reject it as to the nature of the defense under Section 2 (b).

This construction of Section 2(b) certainly places a heavy burden upon the respondent, and it has led to charges that the Commission and the courts have substituted the presumption of guilt for the traditional presumption of innocence in the enforcement of the Act. ${ }^{102}$

If this construction of Section $2(b)$ is accepted by the courts, the only substantive defense to a charge of unlawful price discrimination will be the "due allowance" proviso, and if this fails the Commission in many cases will not even have to show the proscribed injury to competition. The importance of this to the question of the legality of delivered pricing systems becomes apparent when it is recalled that all of these systems, except perhaps the one zone system, produce price differences which cannot be justified by this "due allowance" proviso.

${ }^{99}$ Standard Oil Co., 4I F. T. C. 263 (1946).

${ }^{200} I d$. at 282 .

${ }_{101}$ Id. at 283 .

302 "It seems to me that the trend of both administrative and judicial opinion relating to the RobinsonPatman Act ... has been toward substituting the ancient presumption of innocence for one of guilt, toward a shifting of the burden of proof from the prosecution to the defense. In the case of the Robinson-Patman Act, this trend is evidenced by the practical elimination of the necessity for the prosecution to establish the injurious competitive effect of an allegedly discriminatory pricing policy and by sweeping away the defenses and justifications originally contained in the act." Allen C. Phelps, Hearings, supra note 13 , at 135 . 
It is certainly not clear from a study of the terms of the Act and its legislative history that this is not what Congress had in mind when it passed the Act. Certainly the overriding purpose of the Act was to secure equality of price between buyers, whether they be large or small. ${ }^{103}$ In both houses of Congress Section 2(b) was described as merely a rule of evidence rather than a part of substantive law. ${ }^{10 t}$ The United States Court of Appeals for the Seventh Circuit upheld the Commission's order and approved its construction of Section $2(\mathrm{~b}) .{ }^{105}$ However, it seems unlikely that the Supreme Court would have given so much attention to this defense in the delivered pricing cases if it had considered it as merely a rule of evidence. It is difficult, therefore, to predict the way in which the Court will hold on this issue. In view of the legislative history of the Act, it is quite probable that the Court will affirm the decision of the circuit court despite its rather obvious adherence to a contrary construction in the prior cases.

There are no decided cases involving delivered price systems under Section 2 of the old Clayton Act. An important Commission proceeding under this section was the Pittsburgh Plus case, mentioned previously. There the Commission alleged that there were discriminations in price the effect of which was to lessen competition betwen the favored customers of defendant and those discriminated against, and to lessen competition among all the producers of steel. The effect upon competition in the second line was proved by showing the much higher delivered prices charged to buyers west of Pittsburgh as compared with prices charged eastern buyers close to the single basing point, and the resultant inability of these western buyers to compete with the favored eastern buyers. Although it was the delivered price that was alleged to be discriminatory, the Commission in its findings spoke of the difference in mill nets as a measure of the discrimination, and found that the use of the single basing point system deprived purchasers located close to the production point of an advantage in the delivered price which they should have enjoyed over customers of the same seller located farther from the mill.

The injury to competition in the primary line was found in the fact that all steel producers followed the system, thereby producing a condition of matched prices and elimination of price competition among competing sellers.

In 1948 the respondents in the Pittsburgh Plus case narrowed the issue by their petition for review of the question of whether the order forbade the practice of systematically adopting competitors' base prices plus the freight from competitors' places of manufacture and shipment; i.e., whether it forbade freight absorption

${ }^{103}$ See Crowley, Equal Price Treatment Under the Robinson-Patman Act, 95 U. of PA. L. Rev. 306, 343 (1946); see also 80 CoNG. Rec. 8102-8104 (1936).

104 "It is to be noted, however, that this does not set up the meeting of competition as an absolute bar to a charge of discrimination under the bill. It merely permits it to be shown in evidence. This provision is entirely procedural. It does not determine substantive rights, liabilities, and duties." Representative Utterbacl, 80 CoNG. Rec. 9418 (r936).

"The proviso [Sec. 2(b)] to which he refers is simply a rule of evidence rather than a part of substantive law." Senator Van Nuys, 80 CoNG. Ric. 9903 (1936).

${ }^{105}$ Standard Oil Co. v. Federal Trade Comm'n, I73 F. 2 d 210 (C. C. A. 7 th 1949). 
when not accompanied by phantom freight. They contended that this was really only the question whether they should be allowed to meet competition in good faith.

The Commission in its brief on this point contended that freight absorption was present and considered in the case; that freight absorption was so woven into the basing point system that it was not possible to prevent the one and permit the other; that the petitioners' practice of systematic freight absorption involved unlawful price discriminations under the Clayton Act, Section 2; that it did not constitute a good faith effort to meet competition "because it is part of a system by which petitioners and their competitors are enabled to match each others' delivered prices and neutralize the competitive effect of all cost differences; that it is not the meeting of individual competitive situations, and that like phantom freight it may injure competition among petitioners' customers." ${ }^{\text {"106 }}$ It is important to note here that it was contended by the Commission that the injury to competition in the second line was caused not only by the higher delivered prices imposed as a result of the phantom freight, but also by the fact that because of freight absorption the buyers located next to the western mill paid a higher net price, thus placing them at a competitive disadvantage with eastern buyers paying a lower net price. This is a corollary to the Commission's arguments that the mill net is the true price and that the nearer buyer is entitled to a lower delivered price than those more distant from the plant. As will be brought out later, the upholding of this type of argument to prove injury to competition in the second line would make individual and independent use of any of these delivered price systems illegal under the amended Clayton Act. The extent to which this concept of injury to competition is accepted by the courts and utilized by the Commission will determine the legal fate of the individual, independent use of the one zone price system.

In the Corn Products case ${ }^{107}$ the individual use of a single basing point system was attacked as producing discriminations in price in violation of the amended Clayton Act. In that case the Commission found that the respondent used Chicago as a basing point for all his delivered price quotations although he had plants both at Chicago and Kansas City. The Commission also found that in his use of the system he discriminated in price between his customers with the result that substantial injury was done to his competitors, competition with respondent tended to be hindered, suppressed and obstructed, it tended to create a monopoly in respondent, and substantial injury to competition among purchasers of such product was effected because of the lower prices granted to preferred purchasers and not to others.

The Commission based its finding of discrimination in price upon the fact that there were differences in prices to purchasers located in twelve different cities which differences could not be justified by the "due allowance" proviso. It found that purchasers located closer freightwise to Kansas City than Chicago paid a price

${ }^{108}$ Brief for Appellees, United States Steel Corp. v. Federal Trade Comm'n, Docket No. 6796 (C. C. A. $3 \mathrm{~d}$ 1938).

${ }^{107}$ Corn Products Refining Co. v. Federal Trade Comm'n, 324 U. S. 726 (I945). 
which included freight costs not actually incurred. Although no mention was made in the findings of the mill net, the findings indicated that the Commission's position was that there was a discrimination whenever the delivered price did not include the true transportation costs. If this be true, then, of course, the mill net would have to be examined to determine if the delivered price included freight costs different from those actually incurred.

The finding as to the adverse effects on competition was based upon the fact that purchasers from respondent were competitors in the sale of candy in which glucose was a principal ingredient. It was found that a difference of a fraction of a cent in the price of this candy would be sufficient to attract customers from one competitor to another. Consequently, it was concluded that the buyers paying the higher prices were injured in their efforts to compete with those who received the lower prices. It was found further that several candy makers located near Kansas City were forced to relocate by moving closer to Chicago in order to compete effectively.

The Supreme Court, in reviewing the decision of the circuit cour ${ }^{108}$ which upheld the Commission's order, noted the Commission's findings as to price differences in the twelve representative cities and pointed out that the net return at the Kansas City plant varied according to the phantom freight included in the delivered price. It referred to the Commission's findings that buyers in cities other than Chicago paid higher prices which resulted in higher costs of producing candy and in a lessening of these buyers' ability to compete with buyers in Chicago. In answer to the petitioners' argument that their pricing system did not result in price discriminations within the meaning of the Robinson-Patman Act the Court said:109

Petitioners' pricing system results inevitably in systematic price discriminations, since the prices they receive upon deliveries from Kansas City bear relation to factors other than actual costs of production or delivery.

It then called attention to the varying net prices received by the petitioners from sales in the selected twelve cities and to the phantom freight collected from these sales and concluded: ${ }^{110}$

The price discriminations resulting from this systematic inclusion of the freight differential in computing the delivered price are not specifically permitted by the statute. Hence they are unlawful, unless as petitioners argue, there is an implicit exception to the statute for such a basing point system.

This is a direct approval of the Commission's finding that delivered prices which fail to make due allowance for differences in the cost of delivery are discriminatory. The variations in mill net here were taken as proof that due allowance had not

\footnotetext{
${ }^{108}$ I 44 F. 2 d 2 II (C. C. A. 7 th 1944 ).

${ }^{109} 324$ U. S. 726, 732 (1945).

110 Id. at 733 .
} 
been made. In another part of the opinion the Court showed that it endorsed this concept of discrimination: ${ }^{111}$

Further we have seen that prices in cities to which shipments are made from Kansas City are frequently discriminatory, since the prices in such cities usually vary according to factors, phantom freight or freight absorption, which are unrelated to any proper element of actual cost.

The Court next overruled the petitioners' contention ${ }^{112}$ that the elimination from the Robinson-Patman Act of the definition of the word "price" as the mill net to the vendor showed a Congressional intention to sanction all basing point systems. ${ }^{113}$

In its examination of the findings as to the effect on competition of petitioners' discriminatory prices, the Court seemed to ignore the charge and findings of injury to competition in the primary line and considered only the injury to competition in the second line, that is, among customers of the petitioners. The Court sustained the Commission's finding of probable injury to competition based upon evidence that a small variation in the price of glucose was enough to divert business from one candy manufacturer to another, and upon evidence that some customers of the petitioners had actually been forced to relocate.

The competition which the Commission found probably would be injured by the use of the basing point system was that between respondent and his competitors (primary line), and that among the customers of the respondent (second line). The former injury is that which the discriminatory seller imposes upon his competitors by quoting lower prices to their customers so as to endanger their continued ability to compete with him, thus tending to give the seller a monopoly in the commodity sold. This concept of injury to competition is not a new one and is the one mainly responsible for the passage of the original Clayton Act. It is surprising that the Commission did not emphasize this concept of competitive injury, as its predatory nature would preclude its being defended as a "good faith" meeting of the "equally low price of a competitor."114

The Staley case ${ }^{115}$ was a companion case to the Corn Products case. The respondent in that case had one plant at Decatur, Illinois, and sold all his products at delivered prices calculated by adding to a base price at Chicago the freight from Chicago to the buyer's destination. The Commission's complaint, findings, and order closely parallel those of the Corn Products case with the one exception that the only competitive injury alleged was that among the customers of the respondent.

${ }^{111} I d$. at 739 .

112 See note 89 supra.

113 "We think this Iegislative history indicates only that Congress was unwilling to require f.o.b. factory pricing, and thus to make all uniform delivered price systems and all basing point systems illegal per se. And to the contrary we think that it left the legality of such systems to be determined accordingly as they might be within the reach of Section $2(a)$ as enacted, and its more restricted prohibitions of discriminations in delivered prices." 324 U. S. 726, 737 (1945).

:14 For an interesting account of the predatory nature of basing point systems, see Macruvp, op. cit. supro note 46 , c. 5 .

${ }^{116}$ Federal Trade Comm'n v. A. E. Staley Mfg. Co., 324 U. S. 746 (1945). 
The Commission's order was vacated by the Court of Appeals for the Seventh Circuit. One majority judge believed that the respondent had rebutted the Commission's prima facie case by showing that he had adopted the basing point system in good faith to meet the equally low prices of his competitors. Another decided that the Commission had not made out a case of unlawful price discrimination. The third judge dissented and would have upheld the Commission's order. The Supreme Court in reviewing the case on certiorari reversed the decision of the lower court and upheld the Commission's finding that the respondent's pricing system involved price discriminations prohibited by Section 2(a) of the amended Clayton Act. As to these discriminations the Court had this to say: ${ }^{116}$

As we hold in the Corn Products Refining Co. case with respect to a like system, price discriminations are necessarily involved where the price basing point is distant from the point of production. This is because, as in respondent's case, the delivered prices upon shipments from Decatur usually include an item of unearned or phantom freight or require the absorption of freight with the consequent variations in the seller's net factory prices. Since such freight differentials bear no relation to the actual cost of delivery, they are systematic discriminations prohibited by Section 2 (b) whenever they have the defined effect upon competition.

The only question which the Court felt obliged to determine was whether the respondent had justified his discriminations under the "good faith" proviso of Section 2(b).

The respondent attempted to justify the discriminations by showing that he merely adopted the pricing system being utilized by his competitors when he entered the market. The Court rejected this argument, however, on the reasoning that he could not justify his discriminations by showing that he adopted the unlawful system of a competitor.

The Court recognized that the seller's adoption of a competitor's prices by including unearned freight in its delivered price was no different from maintaining an f.o.b. factory price high enough to take advantage, through freight absorption, of a competitor's higher price based on its higher cost of delivery, and that such action caused an artificially high price level. This was a recognition by the Court of the fallacy of seeing phantom freight as the only evil in the basing point system, and strongly indicates that a defense under Section 2(b) would not be any more available to sellers utilizing a freight equalization system involving only freight absorption. ${ }^{117}$

In rejecting the respondent's defense under Section $2(\mathrm{~b})$ the Court also remarked:118

${ }^{110} \mathrm{Id}$. at 750,751 .

117 "So far as injury to competition among the customers of a single seller is concerned, the discrimination reflected by the varying mill nets of freight absorption may hurt a customer just as much as an equal amount of discrimination taking the form of phantom freight." Wooden, The Concept of Unlawful Discrimination as It Applies to Geographic Price Differences, 37 Geo. L. J. 166, x80 (1949).

For a more sophisticated explanation of the fallacy of attempting to differentiate between the freight absorption and phantom freight involved in basing point systems, see Maceitup, op. cit. supra note 46 , at $149-151$.

${ }^{118} 324$ U. S. 746,757 (1945). 
We cannot say that a seller acts in good faith when it chooses to adopt such a clearly discriminatory price system, at least where it has never attempted to set up a nondiscriminatory pricing system, giving to purchasers, who have the natural advantage of proximity to its plant, the price advantages which they are entitled to expect over purchasers at a distance.

This indicated the Court's approval of the Commission's argument, made in the Pittsburgh Plus case and in several proceedings ${ }^{119}$ involving collusive use of a delivered price system, that the purchasers located close to the plant have a natural right to a price advantage over those located a greater distance therefrom, and that any system not giving them that advantage is discriminatory. ${ }^{120}$

If delivered prices which do not make due allowance for differences in cost of delivery are discriminatory, and if the buyer located closer to the plant has a natural right to a delivered price advantage over more distant purchasers, it follows that in order to determine the presence and extent of discrimination in a delivered price the price without the transportation cost included, that is, the mill net price, must be examined. It is difficult to see how these two propositions could be accepted without accepting as the concept of price the mill net received by the vendor. There is dispute, however, as to whether these two cases represent approval of the "mill net" theory. ${ }^{121}$ It is, of course, true that there were differences in the sellers' delivered prices in these cases which could not be justified under the "due allowance" proviso. Consequently, a decision on the "mill net" question was not necessary to a determination of either case. The many references of the Court to the mill net price cannot be overlooked, however, and the fact that the cases could have been

${ }^{110}$ American Chain Institute, Inc., Docket No. 4878 (1945); American Iron and Steel Institute, Docket No. 5508; Clay Sewer Pipe Ass'n, Docket No. 5484; National Lead Co., Docket No. 5253 (1944).

${ }_{120}$ One writer characterizes this argument as "a conclusion which lacks support" and says, "It is just as easy to argue that competition would be fostered if buyers were not penalized by location at a distance from the factory." Hilder, supra note 90, at $4 \mathrm{I} 4,4 \mathrm{r} 5$.

Another answers this contention: "Now it is obvious that unless buyers have that right then sellers have the right to charge buyers near the factory more than those at a distance. That involves charging them phantom freight or refusal to make due allowance for differences in cost of delivery. It may 'be just as easy' to contend that competition would be fostered if distant buyers were not penalized but it is not just as sound. Whatever penalty they are under it is one imposed by nature or by their own choice of location and not by fiat of the seller on nearby purchasers. That penalty is the act of a discriminator." Wooden, stupra note 8r, at 12.

121 "Obviously if due allowance is made there will be no difference in the mill net or f.o.b. factory prices applying to the various destinations involved. To whatever extent due allowance is not made it will reflect itself in varying net prices and the amount of the variation would be the amount of the discrimination." Wooden, sipra note 117 , at 167 .

"The Court evidently found the difference between the delivered prices on Corn Products' shipments from Kansas City to have no reasonable explanation, since these differences did not reflect differences in freight costs from Kansas City. To make this finding it was not necessary to consider mill net returns." Hilder, stipra note 90, at 416.

"In each case the Supreme Court referred, in part, to the discriminatory 'mill nets' received by Corn Products and Staley in their use of basing points other than points of shipment, but affirmed the Commission's orders on the ground that there were differences in the delivered prices, which could not be justified by the sellers. The 'mill net' theory of price discrimination, thus, although frequently referred to has not been determinative in any of the cases decided so far." Haslett, supra note 94, at 460. 
decided without a consideration of the seller's mill net does not definitely settle the question of whether they were so decided.

The Court further confused the issue of its acceptance of the "mill net" concept of price by adding, after its discussion of discrimination and rejection of the Section 2(b) defense: $:^{122}$

But it does not follow that respondents may never absorb freight when their factory price plus actual freight is higher than their competitors' price, or that sellers, by so doing, may not maintain a uniform delivered price at all points of delivery, for in that case there is no discrimination in price.

Defenders of the one zone system have seized upon this statement as showing an express court sanction of such systems, and as express rejection of the "mill net" theory. ${ }^{123}$ The chief proponent of the "mill net" theory, on the other hand, has described this statement of the Court as "a momentary aberration of thought," and mere "dictum."124

The statement certainly indicates that the Court gave little deliberative thought to the actual nature of a one zone system, because it violates the two propositions which the Court apparently accepted in holding the individual seller's use of the single basing point system illegal in these two cases. These are: (I) delivered prices which do not make due allowance for differences in delivery costs are discriminatory; and (2) the buyer close to the factory has a right to a delivered price advantage over buyers located a greater distance therefrom. Furthermore, the Court speaks of maintaining a uniform delivered price system by means of freight absorption when in fact such a system also inevitably contains an element of phantom freight in that the averaging of the freight costs among buyers results in the nearby buyer paying an imputed freight factor greater in amount than the actual freight of such buyer.

In a case involving directly the legality of a one zone system wherein the Commission would be certain to point out these aspects of the one zone system, the Court probably would not let this dictum prevent it from holding that the one zone system inevitably produces discriminatory prices.

These two cases indicate that in basing point cases where the injury to competition is on the buyer's side the defense of meeting a competitor's equally low price in good faith will have a very narrow scope of application, if indeed it can ever be successfully urged. It is clear that if there is an industry-wide use of the system, either the single, multiple or plenary type, this defense will fail. Likewise, where the seller uses a pricing formula under which he follows a discriminatory

${ }_{122} 324$ U. S. 746,757 (1945).

193 "The Court could hardly have indicated more clearly its view that Section 2(a) has no application to the universal delivered price system." Hilder, supra note 90 , at 415.

"Hence we must conclude that Section 2(a) does not reach a uniform delivered price, and in this event it is inherently valid thereunder." Dunn, The Validity of a Uniform Delivered Price, in CCH, Robinson-Patman Act Symposium Before the N. Y. State Bar Ass'n 13, 8 (I947).

${ }^{124}$ Wooden, supra note $8 \mathrm{r}$, at $\mathrm{Ig}$. 
pricing policy even where there may be no competition to justify it, the defense will not succeed. This situation is apt to arise in any instance in which a delivered pricing system is rigidly adhered to. Where a multiple zone system is used in which the differences in price cannot be explained under the "due allowance" proviso of Section 2(a), it would seem that the arbitrary nature of the zone differentials in most instances would preclude any successful use of the Section 2(b) defense. As to the uniform prices within the zones of the multiple zone system and in the one zone system, the existence of phantom freight charges would preclude successful use of the defense.

It is important to note also that although neither of the concepts of injury to competition involved in these two cases depends upon conspiracy or conscious parallel action, there was a background of collusive use of the basing point system in this industry which further indicates that some sort of conspiracy or concerted action is essential to the effective functioning of a basing point system of pricing. ${ }^{125}$

The most recent delivered pricing case involving application of the amended Clayton Act to be decided by the Supreme Court was Federal Trade Commission v. Cement Institute, ${ }^{126}$ the first count of which, alleging a combination to hinder and restrict competition, was discussed supra. The second count of the complaint in this case charged that this collusive use of the multiple basing point system of delivered prices constituted a combination to discriminate in price which resulted in discriminations in price in the sale of cement in violation of Section 2(a) of the amended Clayton Act. This count alleged that the delivered price was not the true price, and that "in order to derive the true price received, the price actually paid to the carrier for transportation of the cement to the buyer must be deducted from the delivered price."127 It further alleged that the discriminations were made in order to destroy competition in price among the various sellers in violation of Section 2(a) of the amended Clayton Act, and that their effect was to destroy competition among all sellers granting the discriminations.

The Commission found that the systematic discrimination in mill nets was an inherent and necessary part of the multiple basing point system, which was itself an expression of each seller's effort to match the delivered prices of the other sellers. The use of the system to match prices and thereby avoid price competition was found to preclude any defense of the varying mill nets as being made in good faith to meet the equally low price of a competitor. The Commission concluded that the systematic discriminations in mill nets were discriminations in price unlawful under Section 2(a) of the amended Clayton Act, and that their effect "has been and may be substantially to lessen competition and tend to create a monopoly in the sale and distribution of cement, and has been and may be to injure, destroy

\footnotetext{
${ }^{125}$ See Sheehy, The Legal and Factual Content of Recent Geographic Pricing Cases, 37 Gro. L. J. I83, 200 (1949); see note 46 supra.

${ }^{129} 333$ U. S. 683 (1948).

${ }^{127} 37$ F. T. C. 87,117 (1943).
} 
and prevent competition with respondents who grant and exact such discriminations."128

The Court of Appeals for the Seventh Circuit reversed the Commission on Count II. It agreed that prices involving phantom freight were illegal, but held that those involving only freight absorption came within the good faith proviso of Section 2(b). This Court also, of course, failed to uphold the Commission's findings of conspiracy. ${ }^{129}$

The Supreme Court answered the respondents' contention that their varying net returns did not constitute discriminations under Section 2 (a) by pointing to the decisions in the Glucose cases, and stated that "the combined effect of the two cases was to forbid the adoption for sales purposes of any basing point system."130

The defense of a good faith meeting of competition was disallowed by the Court on the grounds that Section 2 (b) did not permit a seller to employ a pricing system "which constantly results in his getting more money for like goods from some customers than he does from others,"131 and that all of respondents made some sales whose prices were determined by the basing point formula and governed by other base mills. This the Court said was proof of the use of the system as a practice rather than as a "good faith effort to meet individual competitive situations."

So here we see the Court apparently accepting the Commission's theory that it is the difference in mill nets which measures the discrimination, and that the mill net must be taken as the true price. The Commission, of course, did introduce evidence tending to show that the respondents considered the mill net as the true price, but this does not seem sufficient to justify a conclusion that the Supreme Court did not accept the "mill net" concept of price. ${ }^{133}$ Such a rationalization of the case seems even more weak when we recall the reference made to mill nets in the previous cases. In view of the Corn Products, Staley, and Cement cases it seems safe to assume that a finding of discrimination in price within the meaning of Section 2(a) of the amended Clayton Act will be upheld whenever there are differences in the mill nets from the sale of goods of like grade and quality, which do not come within the "due allowance" proviso of that section.

If this assumption is valid, and this test of discrimination is followed in cases dealing with the other delivered price systems, the freight equalization, multiple zone, and one zone price systems also must be held discriminatory, as differences in mill nets not justifiable under the "due allowance" proviso are inherent in and necessarily result from the use of each of these systems. Of course this does not neces-

${ }^{128}$ Id. at 257 .

120157 F. 2 d 533 (C. C. A. 7 th 1946 ).

130333 U. S. 683,723 (1948).

131 Id. at 725 .

${ }^{132}$ Ibid. (Italics supplied.)

${ }^{133}$ One writer contends that the Cement case cannot be cited as one in which the Court defined price as the mill net because of this special evidence introduced by the Commission. He says that "price" in Section 2(a) means "whatever the circumstances of the transaction make it." Sheehy, stipra note 125 , at 218 . 
sarily mean that they are unlawfully discriminatory, as the discriminations must have the effect on competition proscribed by the statute, and there is also the scant possibility of justification under Section $2(\mathrm{~b})$.

The competitive injury found where the price discriminations are the result of concerted use of a basing point system is injury to competition in the primary line, which is not imposed by a single seller, but is the result of the cooperative setting aside of price competition through the deliberate matching of prices. The holding in this case is based upon the collusive maintenance of the basing point system, ${ }^{134}$ but if it be admitted that a parallel or common use of a basing point system in which price discriminations are inherent results in the same matching of prices and setting aside of competition, the proving of conspiracy would seem not to be necessary to prove this injury to competition on the selling side of the market. The Commission recognized this in the Pittsburgh Plus case and found that the discriminations of a single seller using the basing point system were unlawful because they worked this injury to competition where the remaining sellers likewise followed the same system.

The Circuit Court of Appeals in the Conduit case, supra, accepted the proposition that a knowing and parallel use of the basing point system resulted in the individual seller practicing discrimination which had the same effect on competition as was found in this case to be the result of a conspiracy, and the Supreme Court upheld this acceptance of the proposition. True, the Conduit case was decided under the Federal Trade Commission Act and did not involve the Clayton Act, but its reasoning may compel a holding that the individual use of the basing point system with knowledge that others likewise use it, thereby resulting in identity of prices at all points, is unlawfully discriminatory under Section 2(a) of the Clayton Act regardless of any finding of conspiracy. The same reasoning will apply to any of the other delivered price systems which we have considered, if they are used in the same way so as to produce the same matching of prices at all points. Such a holding is not so startling as it at first might appear if it is but recalled that the injury to competition here is the same as would result from an unlawful conspiracy to maintain the system, and if we remember from our discussion under the Federal Trade Commission Act the very persuasive inferences of conspiracy which arise from such industry-wide use of these delivered price systems.

This case also further narrowed the scope of the area in which the "good faith" proviso of Section 2(b) might be available to a discriminating seller. Where the

\footnotetext{
134 "As we read the order, all of its separate prohibiting paragraphs and sub-paragraphs, which need not here be set out, are modified and limited by a preamble. This preamble directs that all of the respondents 'do forthwith cease and desist from entering into, continuing, cooperating in, or carrying out any planned common course of action, understanding or agreement, combination or conspiracy, between and among any two or more of said respondents, or between any one or more of said respondents and others not parties hereto, to do or perform any of the following things. . . Then follow the prohibitory sentences. It is thus apparent that the order by its terms is directed solely at con. certed, not individual, activity on the part of the respondents." 333 U. S. 683, 727, 728 (1948).
} 
injury to competition is on the seller's side, and results from the cooperative matching of prices so as to eliminate competition, the defense is not available.

The Court also spoke in the Staley case of meeting individual competitive situations, and in both the Corn Products and Cement cases it spoke of systematic price discrimination as showing a lack of a good faith meeting of competition. It is not clear what the Court meant by these statements. Many have construed them to mean that the "good faith" proviso is inapplicable except in isolated transactions. Such a construction would, of course, make the "good faith" defense unavailable to a seller who individually and in an independent manner systematically, or as a business practice, absorbs freight to sell in a distant market in which he is at a disadvantage freightwise. I do not believe that these dicta can be stretched to cover such individual practices of freight absorption, but it certainly is a very strong indication that any seller who rigidly adheres to a delivered pricing system will be unable to defend his price discriminations successfully under Section 2(b).

As far as delivered price systems are concerned, then, the question raised in the Standard Oil case as to the nature of the Section 2(b) defense is of little importance. The question of who must bear the burden of proof as to injury to competition is still very important, however. Since the seller using a delivered price system cannot bring his discriminations within this section, the Commission, if its arguments as to burden of proof are upheld in the Standard Oil case, would in many cases have to show only the use of the discriminatory system in order to prove its case. In view of the past practice of the Commission and the almost insuperable burden that would otherwise fall upon the respondent, it is quite likely that the Commission will be held to have the burden of proving the injurious effect on competition in all cases even if the Section 2(b) defense is held to be not a substantive one. In view of the increasing pressure for amendment to the existing law, it would seem to be to the Commission's advantage to accept the burden voluntarily.

Since we have concluded that all these delivered price systems involve price discriminations, the important question becomes, what will be considered evidence sufficient to prove that these discriminations have the defined effect upon competition?

The pertinent words of the statute are "where the effect of such discriminations may be substantially to lessen competition," etc. The very wording of the statute indicates, and the cases have so held, ${ }^{\mathbf{1 3 5}}$ that an actual injury to competition need not be shown. The latest Supreme Court case to interpret this part of the Act was the Morton Salt case, ${ }^{136}$ which did not involve delivered prices. In this case involving price discounts, the Court said: $:^{137}$

${ }^{105}$ Corn Products Refining Co. v. Federal Trade Comm'n, 324 U. S. 726 (I945); Federal Trade Comm'n v. Morton Salt Co., 334 U. S. 37 (I947).

${ }_{100}$ Federal Trade Comm'n v. Morton Salt Co., 334 U. S. 37 (1947).

${ }^{137} \mathrm{Id}$. at 46 . The Court in the Corn Products case said ". . . The use of the word 'may' was not to prohibit discriminations having 'the mere possibility of those consequences,' but to reach those which would probably have the defined effect upon competition." 324 U. S. 726, 742 (I945). The Court took notice of this statement in the Morton Salt case but still concluded that the test was "reasonable possibility." 
After a careful consideration of this provision of the Robinson-Patman Act, we have said that "the statute does not require that the discriminations must in fact have harmed competition, but only that there is a reasonable possibility that they 'may' have such an effect." Corn Products Co. v. F. T. C., 324 U. S. 726, 742.

A careful reading of the Corn Products case will reveal that the Court there did not actually use the test of "reasonable possibility." To say that the Court used the test of "reasonable probability" would probably be more accurate. It is doubtful if the Court in the Morton Salt case meant to depart from its prior interpretation of the statute, and even if it did do so the difference between "possibility" and "probability" may be in effect infinitesimal.138

The Court did suggest, however, that the required injury to competition could be inferred from substantial price differences without any other evidence as to their effect upon competition. The possibility of the Commission adopting such an approach in its delivered price proceedings has caused quite a furor. The Commission, however, has stated that it will not use the concept of injury adopted by the Court in the Morton Salt case. As to the test which it would follow the Commission said:139

The minimum determination of injury should be based upon ascertained facts that afford substantial probability that the discriminations if continued, will result in injury to competition. ... The concept of injury applied in this field must be appropriate to the particular problem and not based merely upon analogy to concepts elsewhere. In basing point cases the Commission will continue to employ concepts of injury similar to those which it has used in the past.

If the Commission is to follow this statement it is important to determine what are "ascertained facts that afford substantial probability that the discrimination if continued, will result in injury to competition," and what are the "concepts of injury" which the Commission has used in the past.

${ }^{138}$ The following question was asked several witnesses in the course of the Hearings pursuant to S. Res. 24I: "Does the law as interpreted by the Court permit the Commission to hold such a practicc illegal if it finds a reasonable possibility of injury to competition?" These answers were receivcd: "I think that was definitely determined in the Morton Salt case." Allen C. Phelps, Chief, Division of Export Trade, Federal Trade Comm'n, Hearings, stupra note 13, at 127. "My answer to that as it stands is 'so,' because I believe there has been a great deal of exaggeration and unfounded assumption created and built upon the literal interpretation of those two words, 'reasonable possibility' I belicve that even the minority in the Morton Salt case did not properly take account of the context in which these two words were used." W. B. Wooden, Associate General Counsel, Federal Trade Comm'n, id. at 729, 730. "Section 2(a) makes a price discrimination unlawful where its effect may be substantially to lessen competition or to injure, destroy, or prevent competition. F. T. C. v. Morton Salt Co. held that a price discrimination comes within the ban of Section 2 if there is 'reasonable possibility' that it will have the defined effect upon competition.

"Prior to this decision it had not been definitely determined whether this section dealt with effect in terms of reasonable 'probability' or reasonable 'possibility.'

"I think it is clear that the Supreme Court has now adopted the latter view; but because of the connotations of the word 'reasonable,' I doubt that the difference between the two interpretations is, as a practical matter, very great." H. A. Bergson, Ass't Attorney General, Antitrust Division, Department of Justice, id. at 1381 .

${ }^{139}$ FTC, Statement of Policy, supra note 8. 
The Pittsburgh Plus and the Glucose cases are the only delivered price cases in which an injury to competition among purchasers from the discriminating sellers was involved. In each case the injury to competition was found in the fact that the buyers discriminated against had constantly paid higher prices for their raw materials and thus could not effectively compete with the favored purchasers. It was shown also in each case that some customers were forced to relocate their businesses in order to continue to compete with the favored purchasers. It is also significant that in each case the buyers paying significantly different prices were in actual competition with each other.

If this concept of injury to competition is followed, an injury to competition among customers is quite likely to be found in any case where a single seller uses a single or multiple basing point system and his customers are in competition with one another, or where a single seller uses a multiple zone system with buyers along the fringes of the zones in competition and paying significantly different prices because of the differentials between zones; the price differentials not being justifiable under the "due allowance" proviso. The possibility of such injury flowing from the single seller's use of the freight equalization system is rather remote as the buyers paying significantly different prices are more apt to be located in different market areas and hence not in competition in resale of the product. Of course, as was seen in the Glucose cases, the competition among purchasers does not have to be in resale of the commodity purchased but may be in the sale of a product manufactured therefrom. The type of the commodity sold under the various systems might be important, therefore, as the probability of competition among purchasers will vary with the commodity. The type of commodity so sold may likewise be important in that the price difference must be great enough so that it may lessen competition substantially. This means that if the product is one for which the freight charge is a relatively important factor there is apt to be a price difference great enough to cause the prohibited effect upon competition, whereas with respect to many products the freight charge is a relatively small fraction of the cost of the goods and the price difference resulting from a failure to make due allowance for delivery costs is not apt to lessen substantially a purchaser's competition with the more favored customer. The one zone system is not apt to cause this type of injury to competition. ${ }^{140}$ For this reason it is believed that the independent use of a one zone system by a single seller will not be held illegal under the Clayton Act, unless it shows a monopolistic purpose, which is rather unlikely.

If the theory, apparently accepted by the Supreme Court, that the customer located close to the plant has a natural right to a delivered price advantage over more distant customers is utilized by the Commission, a concept of injury to competition among purchasers might result under which only the f.o.b. mill formula could escape. In both the basing point and the zone type systems the nearby customer is deprived of this right. An individual seller who independently absorbs

$x^{10}$ "It is not probable that competition among a seller's customers will be injured by the fact that they all acquire goods at the same delivered cost." Ibid. 
freight to meet distant competition deprives the nearby buyer of this right. Under this theory it would be reasoned that if each buyer was charged the same mill price plus actual transportation costs the buyers located close to the plant would receive a lower delivered price and thus would be better able to compete with the distant buyer whose delivered costs would be higher. Conversely, it could be reasoned that to deprive the nearby buyer of this advantage is to prevent his competing with the favored purchaser who has received a lower price than he would have otherwise. This would seem to be a logical extension of the theory of "natural advantage of the nearby customer." However, the Commission has developed this concept of injury to competition in only the Pittsburgh Plus case and has indicated recently that it sees no injury to competition where the buyer is deprived of this "right" by a single seller and not through concerted action. ${ }^{141}$

If present practice and interpretation are followed, the probability of the individual seller's adherence to the single basing point, multiple basing point, freight equalization, or multiple zone systems being declared illegal will depend upon the likelihood of its producing injury to competition between customers of the seller or the customers of such customers. As has been pointed out, such use of the basing point or multiple zone systems is very apt to produce such injury as to make it illegal under the Clayton Act, while the individual seller's use of the freight equalization system is less likely to cause such an injury to this competition. The individual and independent use of the one zone system, although presumably discriminatory, will not produce such an injury to competition as to make it unlawfully discriminatory under the Clayton Act.

I have discussed at some length the concept of injury to competition on the seller's side which was applied in the Pittsburgh Plus and Cement cases; I believe that proof of such injury does not necessarily depend upon a showing of collusive or concerted use of the pricing system, but may be proved by showing conscious parallel use of such systems. The only decided case in which this concept of parallel action was applied, however, is one based primarily upon collusive use of

\footnotetext{
142 "The Commission has challenged uniform delivered pricing only where there is reason to believe that the practice has been observed generally in the industry with the purpose and effect of eliminating price competition among sellers. The Commission has not challenged the independent maintenance of a uniform delivered price by an individual seller. It has not challenged the maintenance of a uniform delivered price by several sellers except where such pricing practices were accompanied by collusion and had the effect of eliminating competition. A proceeding against this type of individual pricing practice would be appropriate only if the practice expressed a monopolistic purpose on the part of the seller who engaged in it or if it injured competition in a substantial manner among the seller's customers." Ibid.

The Chief Economist of the Federal Trade Commission goes a little farther and maintains that the nearby customer has no inherent economic right to a price advantage over more distant customers: "I do not believe in inherent cconomic rights for anybody. I believe that it is desirable, as a matter of public policy, to accord to the buyer the right to try to get the advantage of location and to prevent scllers from collusively depriving him of that right." He said also that in cases in which the Commission has asserted this right, it "was asserting it was wrong for the buyer not to have a chance to scramble for the right on equal terms with the seller." Corwin D. Edwards, Director, Bureau of Industrial Economics, Hearings, supra note 13 , at 1366 .
} 
the basing point system and decided under the Federal Trade Commission Act. ${ }^{142}$ That this concept is applicable also to delivered price systems under the Clayton Act is shown by two recently instituted complaints in which the Commission proceeds against uniform prices within the zones of the multiple zone system on the theory that conscious parallel use of such a system violates Section 2(a), in that the seller's delivered prices do not make due allowance for the costs of delivery, and that the purpose and necessary result of such common discrimination is the elimination of price competition among the discriminatory sellers. ${ }^{143}$

In both cases there is a charge in the first count of the complaint that the respondents engaged in a broad price fixing conspiracy which included the establishment of a zone pricing system. In the second count of the complaint in each case there is a charge that the individual seller violates Section 2(a) by quoting a uniform delivered price.

These cases are important in another respect as they present for direct determination for the first time the question of whether a one zone price is discriminatory within the meaning of Section 2(a). For the first time the issue cannot be decided without a determination of whether the delivered price which does not make due allowance for differences in cost of delivery is discriminatory, and, as a corollary question, whether "price" in such cases can be construed as the mill net return of the seller. In view of the apparent acceptance of these arguments by the Supreme Court in prior cases it seems quite likely that all these questions will be answered in the affirmative.

A contrary result would affect seriously the legal status under the Clayton Act of only the one zone price system. There would still exist differences in the delivered prices of all the other delivered price systems which would seem not justifiable under any provision of the Act.

Since the Federal Trade Commission has declared that it sees no danger to competition among the customers of the seller independently employing the one zone price system, the Commission would need or desire to attack the system only when it expressed a monopolistic purpose or when it was used pursuant to a conspiracy or conscious parallel action. The Commission can effectively attack such uses of the system under the Federal Trade Commission Act either as conscious parallel or concerted action, or as monopolistic oppression.

The Commission likewise can effectively attack the other delivered price systems as unfair methods of competition where the injury is to competition in the primary line through either monopolistic oppression or a cooperative elimination of competition by means of reciprocal price matching.

In fact, it has now become apparent that when the injury caused to competition by the use of a delivered price system is this "cooperative" setting aside of com-

${ }^{163}$ See the discussion of the Conduit case supra, in which an apparent change of opinion by the Federal Trade Commission on the theory of parallelism of action is pointed out.

${ }^{243}$ Matter of Chain Institute, Inc., Docket No. 4878 (I945); Matter of National Lead Co., Docket No. 5253 (1944). 
petition on the seller's side of the market by means of a reciprocal matching of prices, the vulnerability of the system to attack is identical under both the Clayton Act and the Federal Trade Commission Act. Consequently, the conclusions reached as to the legality under the Federal Trade Commission Act of collusive and parallel use of the delivered price systems apply with equal force to the question of the legality under the Clayton Act of such use of the systems. ${ }^{\mathbf{1 4 4}}$

Since the Commission can secure effective relief by proceeding under the Federal Trade Commission Act when injury to competition in the primary line results from the use of the delivered price systems, it would undoubtedly help to clear up much of the existing confusion if the Commission would in such cases confine its actions to the Federal Trade Commission Act and proceed under the Clayton Act only when competition in the second or third lines has been affected.

$\mathrm{V}$

\section{The Need for Legislation}

The recent delivered pricing cases have given rise to a strong movement for the enactment of legislation to clarify the confused state of the law as to the legality of the various pricing systems and practices.

Many businessmen contend that the law pertaining to geographic pricing practices is so uncertain that the only practical pricing method left to them is the f.o.b. mill formula. Any other method is said to involve unreasonable risks for two reasons: (I) a meeting of competition will be labeled a price fixing conspiracy, and (2) a seller cannot absorb freight to reach a market in which he is at a disadvantage freightwise without being found guilty of unlawful price discrimination.

The first reason advanced for the necessity of adopting an f.o.b. mill formula is predicated upon the assumption that the Federal Trade Commission may not be able to distinguish price identities arising from conspiracy or collusion from those arising from competition. The Commission is not limited to an examination of the price identities to determine if sellers have conspired, however, but may look at the movement of prices in relation to each other and at the long run rigidity-or flexibility of prices.

In addition to the study of prices and their movements, the Commission, as has been pointed out, has almost always relied upon agreement to establish the system, cooperative activities to make it function, and disciplinary measures to secure adherence to it, to prove conspiracy.

It is, of course, true that the Commission did not rely upon conspiracy in the second count of the Conduit case, and that the parallelism of action was not proved in this manner. The existence of tacit conspiracy was so apparent there, however, that it is unrealistic to charge that the Commission mistook competitive action for collusive practices. Indeed, it is submitted that the behavior of prices and of sellers so deviates from the competitive norm where there is collusion or conspiracy, tacit

\footnotetext{
144 See pp. 197-200 supra.
} 
or overt, that the probability of the Commission's confusing the two, especially after a careful investigation, is so very slight that a businessman who honestly desires to compete and who wishes to refrain from collusive action is in no real danger of being accused of such action by the Federal Trade Commission.

In analyzing the contention that legislation is necessary to allow a seller to absorb freight several facts should be kept in mind: (I) It should be understood that a seller can absorb freight without adhering to one of the delivered price systems which I have considered; (2) it should be recalled that the Supreme Court's condemnation of systematic discrimination came in the Cement case under such circumstances that the sellers' systematic discriminations were actually conscious efforts to match prices pursuant to a conspiracy to eliminate price competition among sellers; ${ }^{.15}$ (3) the only cases to reach the Supreme Court in which the Section 2(b) defense of a good faith meeting of competition was involved had to do with situations in which there was a collusive matching of prices, or in which the seller was adhering rigidly to a basing point system and thus doing far more than meeting the actual competition of a competitor; (4) the Supreme Court has not yet held that the Section 2(b) defense is not a substantive one and it may not do so; (5) neither has it held that an individual seller cannot absorb freight as a business practice where his independently and competitively arrived at price plus transportation charges is too high to compete with that of another seller. Of course the argument can be raised that if freight absorption is practiced by several sellers the Federal Trade Commission will confuse the resulting price identities as evidence proving a conspiracy. As pointed out above, however, this is thought to be no real or serious danger.

If the Supreme Court upholds the Commission's interpretation of Section 2(b) of the Clayton Act as embodied in its complaint and findings in the Standard Oil case, particularly its contention as to who must prove injury to competition, a much better case can be made for the desirability of "clarifying" legislation to define more clearly the rules as to freight absorption. As long as the Commission must bear the burden of proof as to the effect upon competition, the individual competitive seller would incur no great risk in absorbing freight to sell in distant markets, regardless of the nature of the defense of meeting competition in good faith.

We can conclude then that where the seller is not adhering to a basing point or zone pricing system, he is reasonably safe in absorbing freight to meet competition. We have seen that the one zone system is relatively safe because of the improbability of its use producing an adverse effect upon competition. Since, however, the illegality of a price discrimination depends upon its effect upon competition, there can be no complete assurance that any pricing practice other than f.o.b. mill pricing cannot be successfully challenged under the amended Clayton Act. This does not mean, however, that businessmen must adopt an f.o.b. mill

\footnotetext{
${ }^{165}$ The Court also spoke of systematic discrimination in the Glucose cases (see pp. 213, 219 supra), but there there was rigid adherence to a single basing point system involving both freight absorption and phantom freight, in an industry in which there was a background of conspiracy.
} 
formula in order to escape an unreasonable risk of being held guilty of an injurious and illegal price discrimination. They can still absorb freight without violating the law if they use reasonable care to avoid price discriminations which are injurious to customers, and if they are reasonably prompt to correct discriminations upon receiving customers' complaints that such injury is being inflicted.

The fact that legislation may not be needed to "clarify" the legal status of freight absorption is not conclusive of the question as to the need for a general legislative overhauling or revision of the antitrust laws. It may well be desirable to examine the antitrust laws in the light of present day conditions and to consider if they are adequate to implement and enforce those policies which are necessary to maintain that type of economy which best serves the public interest.

Such an examination must, however, be conducted in a more objective, publicspirited, and thorough manner than the recent delivered pricing investigations. All viewpoints must be heard, and all interests must be represented, but the proceedings must be as free as possible from the dominance of any self-serving pressure group. Until such an approach to the problem of reformulating antitrust policy can be made, I feel that any attempt to alter the present antitrust policy through legislation is very apt to result in an even further frustration of attempts to preserve that type of economy which is considered to be in the best interests of the country. 